\title{
Did UEFA's Financial Fair Play Harm Competition in European Football Leagues?
}

\author{
Stephan Birkhäuser ${ }^{1}$, Christoph Kaserer ${ }^{2}$, and Daniel Urban ${ }^{3}$
}

\begin{abstract}
When introducing UEFA's Financial Fair Play (FFP) it was argued that as a beneficial side effect competition in European football leagues should become more equilibrated and perceived as being fairer. Based on a hand-collected dataset on league results, player market values as well as investor payments of more than 300 European football clubs, we scrutinize the impact of FFP on the competitive landscape in major European football leagues. By applying a fixed-effect panel regression difference-in-differences approach, we find results that are consistent with the view that FFP might have further amplified the competitive imbalance. This might be caused by the fact that FFP raises some barriers against the entrance of new investors. Moreover, we present evidence that FFP supports the former season's winner in terms of budget shares in the upcoming season. Overall, our results support the view that FFP turns European football leagues less equilibrated and even tends to freeze current hierarchies.
\end{abstract}

Keywords: Football, competition, investors, inequality, financial fair play

\footnotetext{
${ }^{1}$ Stephan Birkhäuser is a former student at Technische Universität München (TUM).

${ }^{2}$ Christoph Kaserer is co-director of the Center for Entrepreneurial and Financial Studies (CEFS) and Full Professor of Finance at the Department of Financial Management and Capital Markets at the TUM School of Management.

${ }^{3}$ Daniel Urban is a postdoctoral researcher at the Department of Financial Management and Capital Markets at the TUM School of Management.

We thank Sabine Lang for outstanding research assistance. All errors are our own.
} 


\section{Introduction}

Since the nineties increasing broadcasting and marketing revenues largely expanded the budgets of professional European football clubs, especially those of the most well-known. Moreover, foreign investors started to target several of these well-known clubs. With Roman Abramovich becoming owner of Chelsea F.C. in June 2003, investor presence at European football clubs has extensively been discussed among officials of the Union of European Football Associations (UEFA), the media, and fans. Interestingly, during the same period the financial conditions of many European professional clubs considerably deteriorated. Franck (2014) reports that in 2011 European top division clubs accumulated net losses of 1.7bn Euro, a number three times as high as in 2007. Evidently, even though clubs' revenues substantially increased since the nineties, their expenses, foremost transfer payments and player wages, did so to a larger extent.

As a reaction to this seemingly unsustainable situation, the UEFA announced in 2010 a set of regulations, known as financial fair play (FFP), aimed - amongst others - at (i) introducing more discipline and rationality in the management of European football clubs, (ii) decreasing the pressure on salaries and transfer fees and (iii) protecting the long-term viability of European club football. ${ }^{1}$ The UEFA's most important lever to achieve these goals was to make financial discipline a prerequisite of club licensing. Simply put, under FFP clubs must (almost) balance "relevant" income with "relevant" expenditures over a three-year period. Most importantly, these rules should prevent clubs from going on excessive shopping tours in- and outside Europe spending money generated through laxly granted loans or injected by financial or private investors. The first assessments under this rule were mandated in 2011, and as of 2013 and 2015, respectively, clubs have to obey to even stricter rules (e.g., UEFA 2010, UEFA 2012, and UEFA 2015). For example, as of 2011, clubs need to prove that they do not have excessive payables towards all types of stakeholders and as of 2013, clubs also have to balance their relevant revenues and relevant expenses as well as their debt capital ("break-even requirements"). Ultimately, by forcing clubs' management to act more responsibly, the UEFA wished to strengthen

\footnotetext{
${ }^{1}$ The UEFA's official goals of FFP are stated on http://www.uefa.org/protecting-the-game/club-licensing-andfinancial-fair-play/index.html.
} 
market discipline - in terms of player wages and transfer payments - to improve the long-term sustainability of European club football.

It should be noted, however, that right from the beginning FFP was also seen as instrument to level the playing field between a few well-known clubs that can easily tap investors', banks', or even taxpayers' money, and the remaining clubs. By doing so, it was expected to make competition more equilibrated and perceived as being fairer. Both effects would be a prerequisite for maintaining fan engagement and public interest at a high level in European football, securing its long-term viability, according to the supporters of FFP. In fact, at the meeting of the UEFA's executive committee in June 2015 the then General Secretary, Giovanni Infantino, highlighted the necessity of further ensuring the competitive balance of Europe's football and the role FFP plays in this respect. Actually, FFP should be an instrument to "bring more clubs to compete at the top table". ${ }^{2}$

Nevertheless, the primary goal of FFP was to establish financial discipline and rationality in the management of European football clubs. The improvement of the competitive balance was rather seen as a beneficial collateral effect. ${ }^{3}$ While there is evidence that FFP was somehow successful in achieving its primary goal, in this paper we focus on giving new insights with respect to the second argument. Actually, we will scrutinize the impact FFP had on the degree of competition in several large European football leagues. For a broader review on the different implications of FFP, cf. e.g., D'Andrea \& Masciandro (2016), Franck (2014), and Peeters \& Szymanski (2014). In terms of competitive effects some critical voices have also been raised against FFP. The criticism mostly was based on the argument that by effectively limiting new outside capital injections, the current hierarchy in the European football leagues will be frozen and future development is jeopardized (Vöpel 2011, Madden 2012, Sass 2012, Madden 2014, Preuss et al. 2014).

However, to the best of our knowledge all the papers dealing with the potential competitive effects of FFP are theoretical, which is not surprising taking into account that the UEFA started introducing FFP

\footnotetext{
${ }^{2}$ Cf. The Guardian, Monday 29 June 2015, https://www.theguardian.com/football/2015/jun/29/uefa-financial-fairplay-investors. In an official document the UEFA also says that by complying with FFP "more clubs can be credible long-term investment prospects"; cf. http://www.uefa.com/community/news/newsid=2064391.html. ${ }^{3}$ We thank an anonymous referee for pointing out this important aspect. From the perspective of the UEFA, the establishment of financial discipline was the major reason for introducing FFP.
} 
more strictly only in 2013. Therefore, this paper aims to contribute to this debate by presenting a first empirical analysis of the potential effects of FFP on competition in the major European football leagues. To this end, we hand-collect a novel dataset that covers league results, player market values as well as investor payments to more than 300 football clubs in the first and second football leagues in five European countries (England, France, Germany, Italy, and Spain) throughout the 2004/2005 to 2014/2015 seasons. In our setting, investor payments are defined as payments of either a high-profile natural person or legal entity that holds a significant share of the club's capital as well as payments of all other high-profile natural persons or legal entities with no shareholdings in the club and no direct or indirect relationship to a sponsor of the club, credit or public sector institution.

Based on this dataset, we find three main results. First, contrary to what has been claimed by the supporters of FFP, we find evidence supporting the view that FFP has further increased the competitive imbalance in European football leagues, as measured by the distribution of game points. Second, it seems that an important driver of this result rests on the finding that a larger number of investors makes a league more equilibrated, because, similar to venture capital, investors might break up established structures and increase competition. FFP, however, tends to raise some barriers against the entrance of new investors. Two more results fit into this picture. We find evidence for FFP leading to an increase in the dispersion of player market values in each league. Also, we can show that positive correlations of investor presence and competition are less pronounced when FFP has been introduced. Third, we find evidence that, after FFP, the share of clubs that were successful in the former season is positively correlated to the overall transfer budgets of the upcoming season. To sum up, all our results are consistent with the view that FFP tends to make European football leagues less equilibrated and to freeze current hierarchies.

An obvious limitation of our results are identification issues. In fact, taking into account that FFP was introduced only recently and for all clubs that qualified for a UEFA competition at the same time, it is difficult to disentangle the impact of FFP from other unobserved variables. We address this issue by using panel regressions accounting for league, club and season fixed effects. In this way we implicitly control for the impact coming from league specific developments (e.g. broadcasting revenues) as well as club specific behavior (e.g. transfer oriented vs. in-house young academies). Moreover, we also 
account for time trends. In addition, we look at different model specifications and sample periods and find similar results. Furthermore, when we conduct a placebo test, we do not detect any effects. Nevertheless, to the extent that the impact of unobserved variables is not constant over time, identification deficiencies might still arise.

The remainder of this paper is organized as follows. Section 2 provides an overview of the relevant literature. In Section 3, we describe the data, while Section 4 presents the results. Section 5 summarizes the main findings and discusses some implications.

\section{Literature review and theoretical considerations}

League inequality has been an increasingly popular topic in sports science and economics. Goossens (2006) examines the competitive balance of eleven football leagues in Europe from the 1960s up to 2005 to determine similarities between different nations, thus concluding whether common regulatory standards should be put in place by the UEFA. Goossens also discusses whether a pan-European league represents a remedy to increasing football league inequality as a result of a few dominant clubs.

Furthermore, Bloching \& Pawlowski (2013) analyze the trends in competitive balance throughout Europe's top five football leagues from 1991 to 2011. They argue that the top leagues in Germany and France are likely to be the most exciting ones even though there is decreasing competition throughout all the football leagues in the sample. They further hypothesize that high Champions League payouts might also foster this development.

The presence of football investors has also been widely discussed in academic research. Based on seven case studies, Hassan \& Hamil (2013) focus their analysis on the implications of different management styles of football clubs. For example, they discuss recent developments such as the increasing commercialization and the growing presence of foreign third-party owners of English football clubs.

Fort \& Quirk (2004) differentiate between leagues composed of owners who wish to maximize the percentage of wins (e.g., lower tier European football leagues) versus those with clubs that wish to maximize profits (e.g., the Premier League). Based on a theoretical model, they argue that the level of competitive balance does not differ in both types of leagues. In addition, Pawlowski (2013) conducts a 
survey among 1,700 football fans in Central Europe and finds that the majority of fans think that investors reduce the audience's excitement for the sport.

In addition, a large literature examines implications of the UEFA FFP regulation on competition. For example, Franck (2014) argues that the three major criticisms of FFP - benefits from substantial injections of "external" money into payrolls (Madden 2014), reductions in competition in the player market without achieving benefits from more balanced competition (Peeters \& Szymanski 2014), and, due to market entry barriers, freezing the current hierarchy of clubs - are essentially unfounded. Franck also suggests that FFP can even increase competition as it reduces conspicuous payments to successful clubs in case of investors who wish to bet on winning teams. D'Andrea \& Masciandro (2016), in turn, reexamine these three critiques and provide some continuative views.

This far, however, there is no empirical study that combines data on investor cash flows to European football clubs irrespective of the investor's ownership status in the club and data on football league inequality and that investigates the effects of FFP. In doing so, we are able to provide empirical evidence on the simultaneous effects of investor presence and UEFA regulations on competition.

In essence, we argue that the introduction of FFP hardened football clubs' budget constraints. Beforehand, soft budget constraints let firms overspend, because, similar to too-big-too-fail banks, there have hardly been credible threats of dissolution or insolvency, which led clubs to operate under "soft budget constraints" (Franck 2014). In this regard, FFP was supposed to end the "zombie race" as a result of irresponsible spending of football clubs. Under the new regime, if UEFA strictly enforces its new financial fair play regulation, violation may result in fines, point deductions, and even in the exclusion or disqualification from competitions.

Therefore, managers and investors may turn more risk-averse, foregoing investments into new players, which could then disrupt the status quo. In a way, FFP penalizes smaller clubs, because in contrast to spending limits on salaries of North American football or basketball players, which are the same for all teams, FFP defines club-specific limits (e.g., Peeters \& Szymanski 2014). Ultimately, we thus posit that FFP will result in an ossification of established hierarchies in football leagues since it reduces smaller clubs' external financing opportunities. For example, could have Manchester F.C. become this 
successful under the current financial fair play regulation and disrupted the ordering of top clubs in the

Premier League?

\section{Recent developments in European football leagues}

During the 1990s, the first European football leagues had been generating annual revenues of about several hundred million Euros. At the turn of the millennium, however, major changes such as increasing investor presence, internationalization and changes in consumer behavior affected the core business model, which resulted in an extraordinary growth in sales in the football industry. Over the last years, the Premier League was able to position itself as a market leader in terms of the revenues of its clubs (Figure 1). While total sales for the first leagues in France, Germany, Italy, and Spain amounted to about 1,250 to $2,000 \mathrm{~m} €$ during the $2012 / 2013$ season, the Premier League realized sales of almost $3,000 \mathrm{~m} €$.

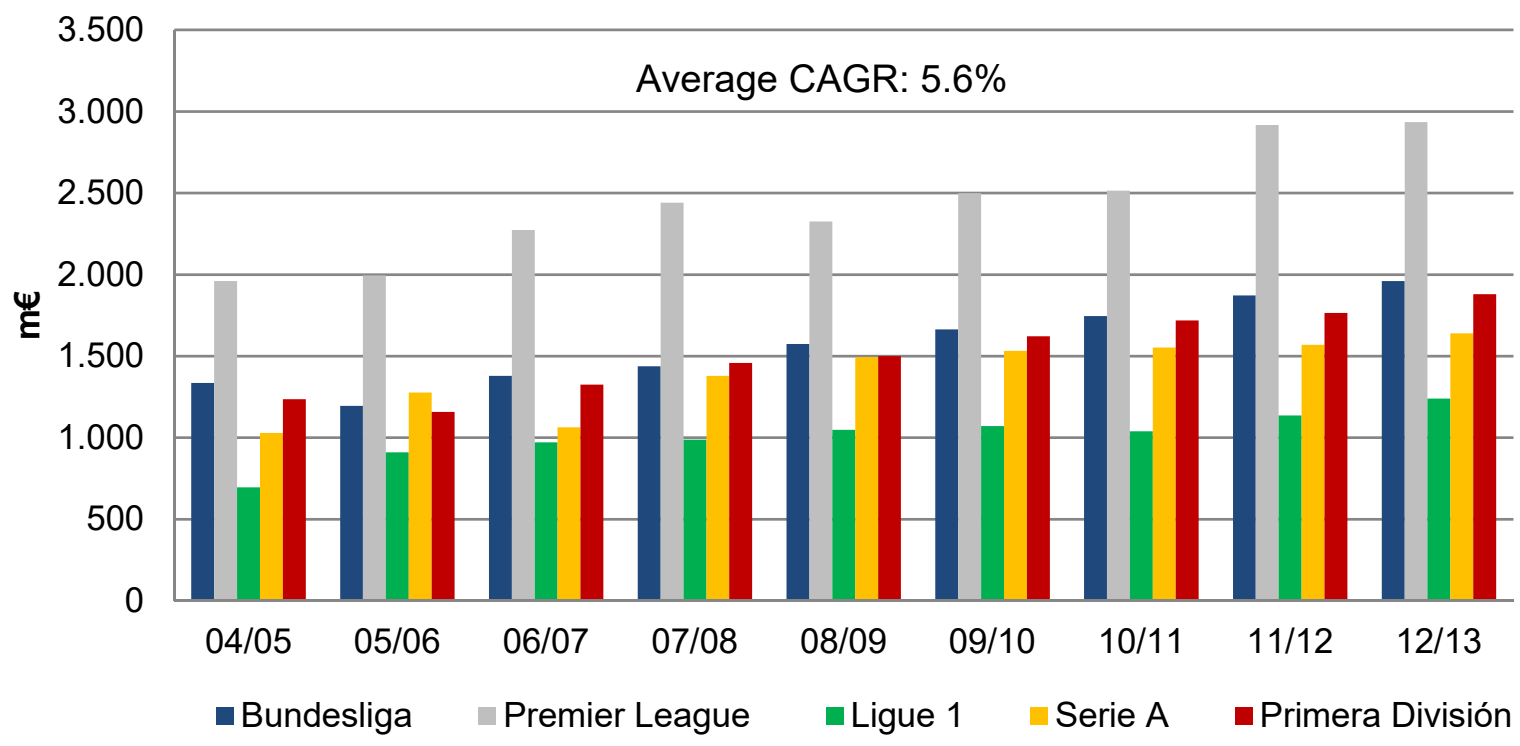

Figure 1: Revenues in major football leagues in Europe (Source: Soriano, 2014).

This dominance is likely to pertain, merely due to considerable imbalances in the commercialization of television rights across the major European football leagues, particularly due to the latest, recordbreaking television rights contract signed for the Premier League in 2015. The high amount of sales can at least partly be explained by the dominance of the Big Four clubs (Chelsea F.C., Manchester United F.C., Arsenal F.C. and Liverpool F.C.) in the mid-2000s and the rising success of their pursuers, Manchester City F.C. and Tottenham Hotspur F.C. since 2009. Thereby, the Premier League more likely could offer more top-class matches than any other national competition in European football, leading to increasing offers for television rights by the competing media giants BT and Sky. 
Besides revenues from broadcasting, game day revenues from ticket sales and advertising revenues from sponsors as well as merchandising deals constitute the three most important sources of revenues for football clubs (e.g., Teichmann, 2007).

Recently, UEFA prize money has also become an important source of revenue for football clubs. Figure 2 shows that, on average, UEFA payouts to the clubs competing in the Champions League and Europa League have doubled throughout the last decade. Thereby, more and more clubs feel obliged to qualify for these two European tournaments as failure leads to a drop in prize money, fewer merchandising sales, and deterioration in the value of the club brand. Declining UEFA prize money may even force clubs to cut budgets and sell players. The increasing importance of international football tournaments might thus be likely to split football clubs into two segments: major clubs with strong international brands and local or regional clubs forced to focus on their regional identity.

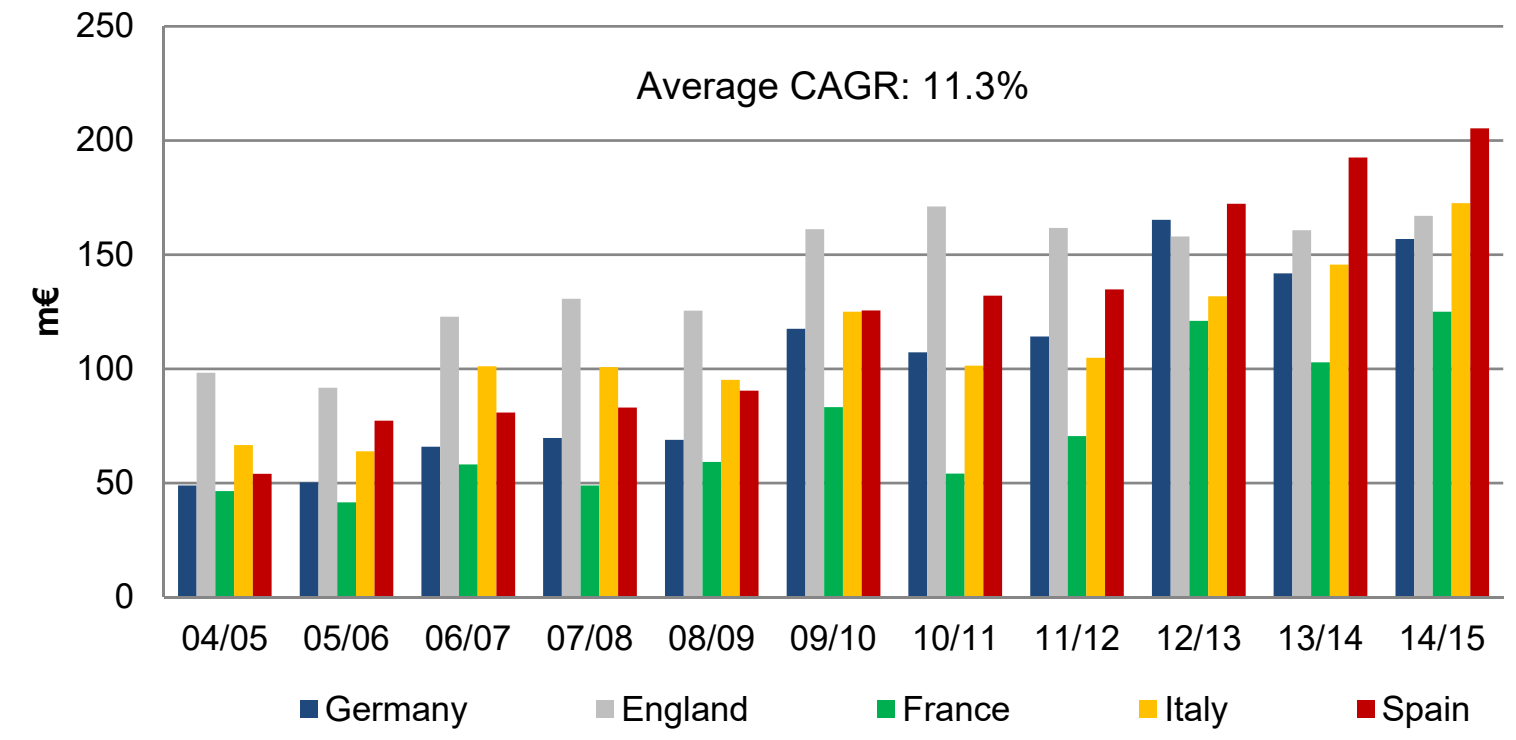

Figure 2: UEFA prize money paid to major European football leagues (Source: Own calculation based in prize money awarded by the UEFA).

The increasing importance of international success is also accompanied by higher expenditures for players (Figure 3). Throughout the last decade, player market values increased by about $100 \%$. This effect is consistent across all major European football nationalities. Not surprisingly, player market values are highest in the first two English football leagues. It is likely that external financing by investors such as Roman Abramovich (Chelsea F.C.) and Sheikh Mansour (Manchester City F.C.) may have amplified the development of higher player market values and thereby increasing costs to English 
football clubs. For example, Manchester City F.C. received investor payments of about 1,300m€ during the sample period. In the following sections, we thus shed new light on the presence of investors in major European football leagues and their implications on competition in national football leagues.

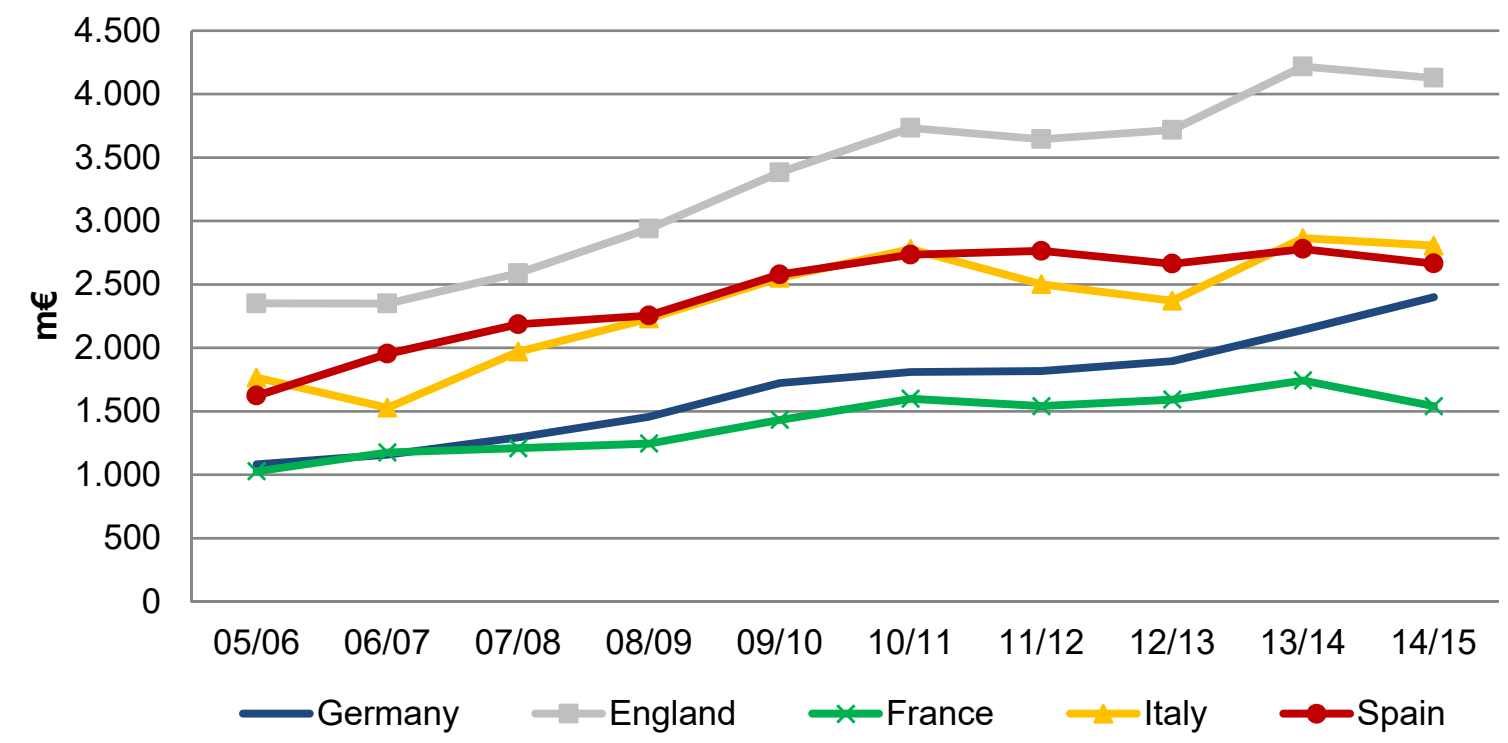

Figure 3: Player market values in major European football leagues (Source: Own calculation based on data by www.tm.de).

However, despite increasing revenues and player market values, many football clubs have recently struggled financially. For instance, aggregate losses reported by top-division clubs in Europe increased from $600 \mathrm{~m} €$ in 2007 to $1.7 \mathrm{~b} €$ in 2011 (UEFA 2013). Furthermore, at that time, 38\% of clubs had negative equity, i.e., debt exceeded total assets (UEFA 2013). Thus, to improve the financial stability of European football clubs, the UEFA has legislated FFP. In the following we will examine the effects of the FFP regulation on football league competition.

\section{Data}

In this paper, we compile a representative dataset that covers 305 individual football clubs across the first and second leagues in five European countries throughout the 2004/2005 to 2014/2015 seasons. The countries in the sample are England, France, Germany, Italy, and Spain. As the sample period extends to more than a full decade, we carefully check for clubs that advanced from lower to higher leagues and vice versa.

In the remainder of this section, we provide some evidence on competition in European football leagues based on several measures of competitive balance. Furthermore, we describe how we measure investor 
payments to European football clubs. Finally, we also explain several control variables used in regression specifications to mitigate concerns about omitted-variables bias.

\section{Competition in European football leagues}

Previous literature has established a wide range of other measures of competitive balance. ${ }^{4}$ In this study, we examine both long-term and short-term aspects of competitive balance. The first measure, the socalled Theil index, analyses betting odds for individual matches to compare the uncertainty of the match outcome (home victory, draw, or away victory). The other two measures capture league inequality on a long-term basis. The Herfindahl-index of competitive balance (HICB) and the C5 index of competitive balance (C5ICB) refer to the distribution of final points of all competing teams (HICB) or the share of the five most successful ones (C5ICB) in a given season. Besides the two time dimensions, two different data sets - betting odds and final points - enable us to draw robust conclusions irrespective of the measure for the level of competition. Other potential measures of competitive balance are, for example, the competitive balance ratio by Humphreys (2002), which is based on team and league results, or mediumterm measures such as the UCS measure by Janssens \& Késenne (1987), which reflects for a given match day, the number of points a team needs to score so that it wins the championship. However, as Bloching \& Pawlowski show for a recent time period, all the above measures of competitive balance yield relatively similar results. Therefore, we assume that by relying on both long- and short-term measures based on league results and betting odds, our results do not only apply to a single measure of competitive balance.

The Theil index, originally developed by Theil (1967), is based on betting odds. Betting odds comprise all historic and current information regarding the possible outcome of a match such as the players' conditions, injuries, or home field advantage. Thus, according to Pope \& Peel (1989), betting odds represent an efficient measure for the uncertainty and therefore for the short-term competitive balance of a football league. In line with Czarnitzki \& Stadtmann (2002), the Theil index can be calculated as

$$
\text { Theil index }=\sum_{i=1}^{3} \frac{p_{i}}{\sum_{i=1}^{3} p_{i}} \log \left(\frac{\sum_{i=1}^{3} p_{i}}{p_{i}}\right)
$$

\footnotetext{
${ }^{4}$ Bloching \& Pawlowski (2013) provide an extensive overview of existent measures of competitive balance.
} 
where $p_{i}$ refers to the probabilities of the three possible outcomes of each match (win, loss, draw). The arithmetic mean of all Theil indexes over all the matches in a given season results in the Theil index for that season. The Theil index increases with a higher (a priori) uncertainty of the match outcome. Thus, the higher the Theil index, the more equal a given football league. To obtain the probabilities $p$ for the different match outcomes, we calculate the inverse of the (decimal) betting odds retrieved for 3,000 matches from www.football-data.co.uk. In doing so, we also take the margins of the bookmakers into account.

The Herfindahl-index of competitive balance (HICB) is a modified version of the Herfindahl (Hirschman) index. The original Herfindahl (Hirschman) index (HI or HHI) is a statistical concentration measure (Hirschman, 1964). The HI of competitive balance (HICB) compares the proportion of the observed HI to the HI of a perfectly balanced league and is measured, according to Depken (1999) and Michie and Oughton (2004) as

$$
\mathrm{HICB}_{\mathrm{t}}=\frac{\sum_{i=1}^{\mathrm{N}} s_{i, t}^{2}}{1 / N_{t}} * 100
$$

where $s_{i, t}$ denotes the share of points of team $i$ at the end of season $t$, and $N_{t}$ the total number of clubs in a league. As the HICB decreases with a higher level of competitive balance, we employ the negative HICB so that the Theil index and HICB are positively correlated.

Finally, we calculate the five-club concentration ratio (C5), which relates the points of the best five clubs in a given season to the points scored by all clubs in that season. We further adjust the five-club concentration ratio by differences in league size $\left(N_{t}\right)$ to arrive at the $\mathrm{C} 5$ index of competitive balance (C5ICB), defined by Michie and Oughton (2004):

$$
\mathrm{C} \mathrm{ICB}_{\mathrm{t}}=\frac{\sum_{\mathrm{i}=1}^{5} \mathrm{~s}_{\mathrm{i}, \mathrm{t}}}{\frac{5}{\mathrm{~N}_{\mathrm{t}}}} * 100
$$

where $s_{i, t}$ denotes the shares of points of team $i$ relative to the league as a whole.

Similarly to the HICB, the C5ICB decreases with a higher level of competitive balance. Thus, we also use the negative $\mathrm{C} 5 \mathrm{ICB}$ to measure football league inequality. 


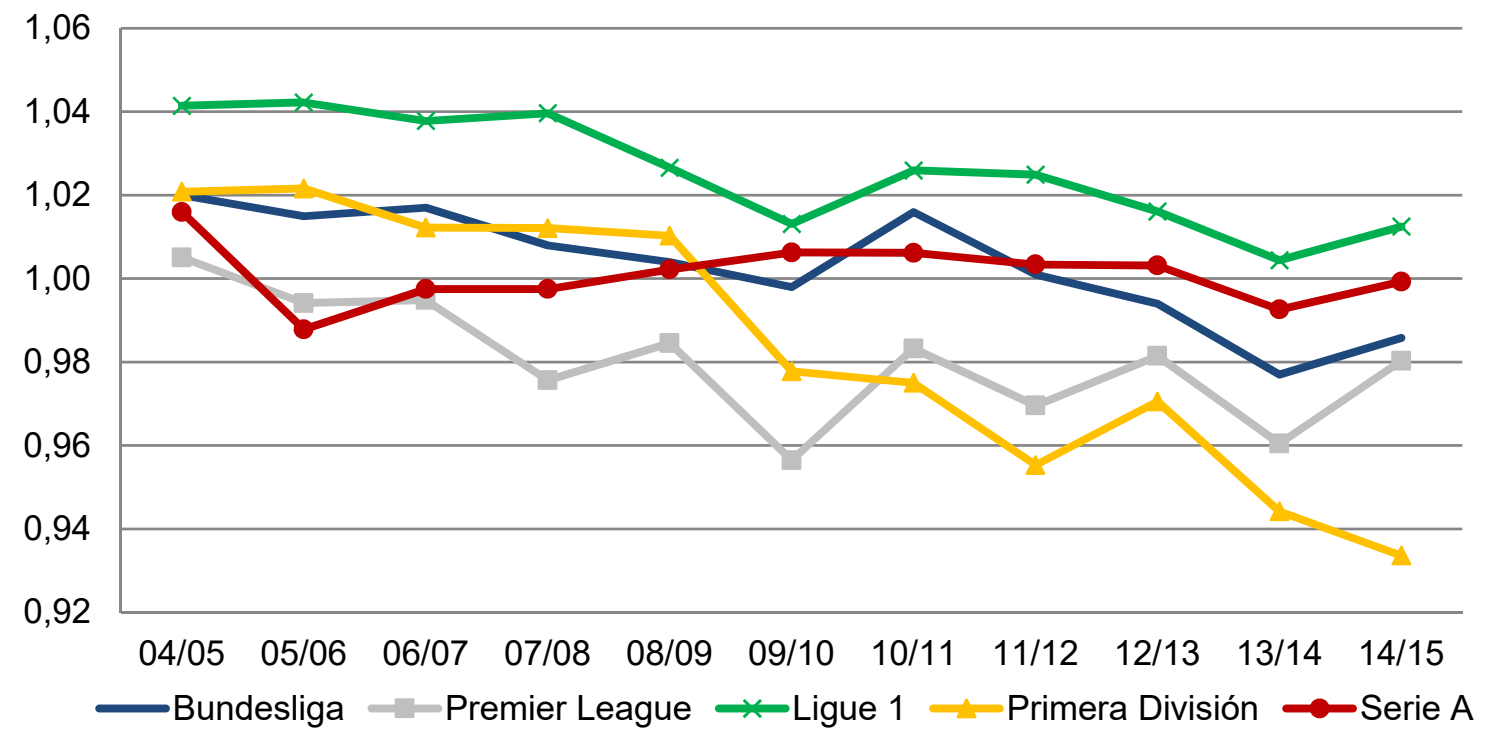

Figure 4: Theil index for the highest European football leagues (Source: Own calculation).

The developments of the three competition measures over time are displayed in Figures 4 to 7 . In line with recent evidence by Bloching \& Pawlowski (2013), we find that competition has on average decreased throughout the sample period. For example, the average share of points of the five best clubs (not normalized by league size) across all the first leagues increased from about 0.35 (2004/2005) to about $0.38(2013 / 2014)$ or by about $9 \%$ (Figure 7), which corresponds to a decrease in the average negative C5ICB from -136 to -148 (Figure 6). Similar conclusions can be drawn based on the other two competition measures. Thus, it could be that the decrease in competition stems from investor presence as most of the investors' money was paid to clubs in the first leagues. In the next section, we examine this relation more formally.

Furthermore, the first French football league (Ligue 1) is generally the most balanced one. Compared to the other European football leagues, competition is modest in the German Bundesliga. Finally, competition is lowest in the English Premier League and the Spanish Primera División. 


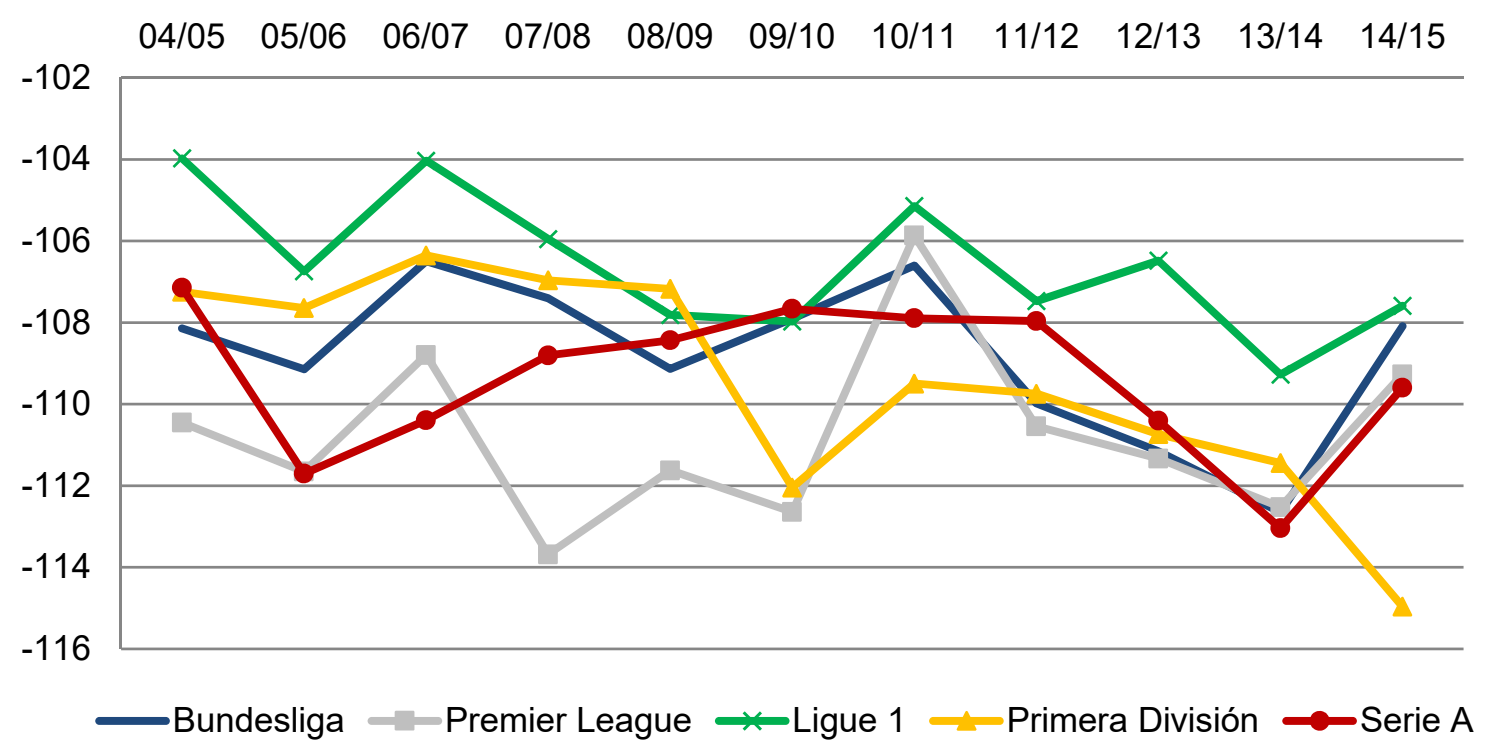

Figure 5: Negative HICB for the highest European football leagues (Source: Own calculation). 


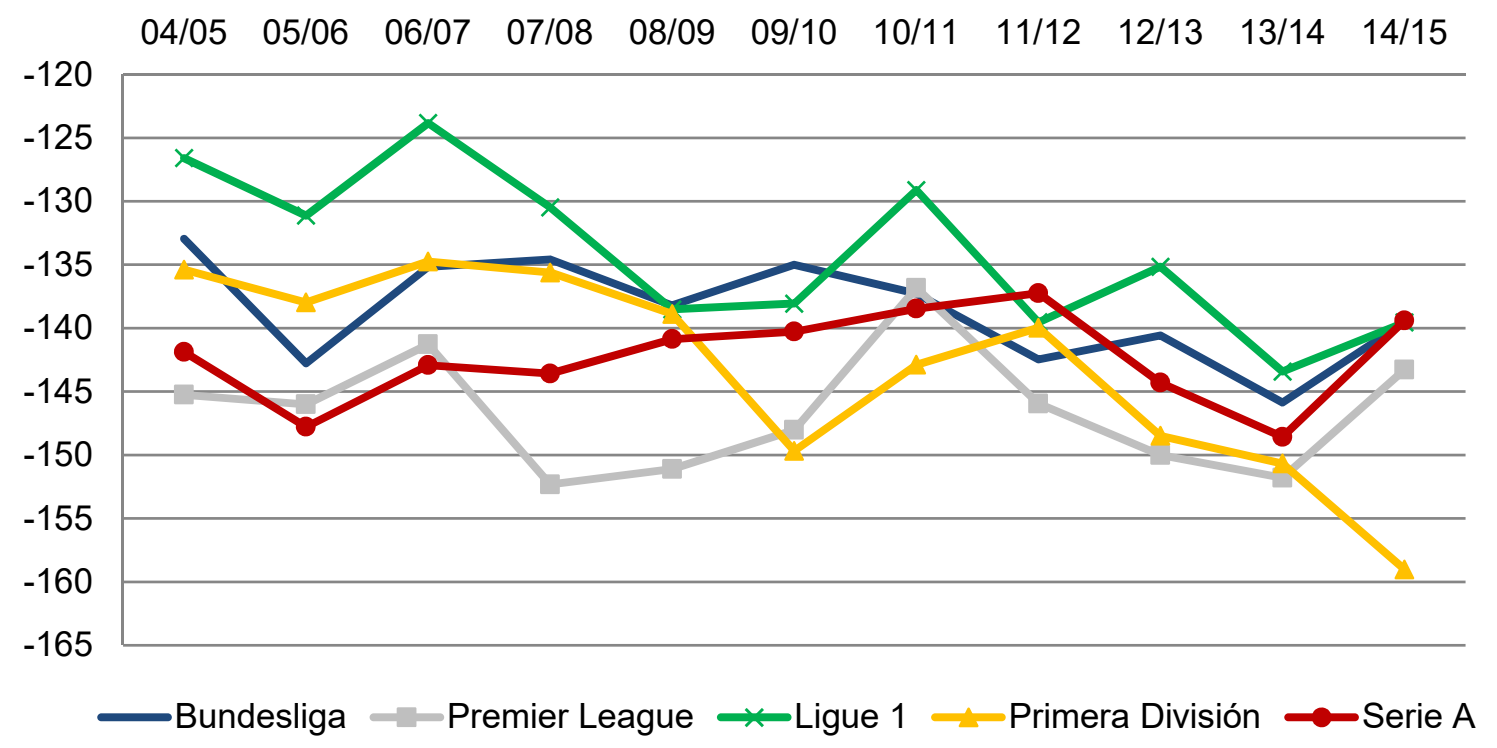

Figure 6: Negative C5ICB for the highest European football leagues (Source: Own calculation).

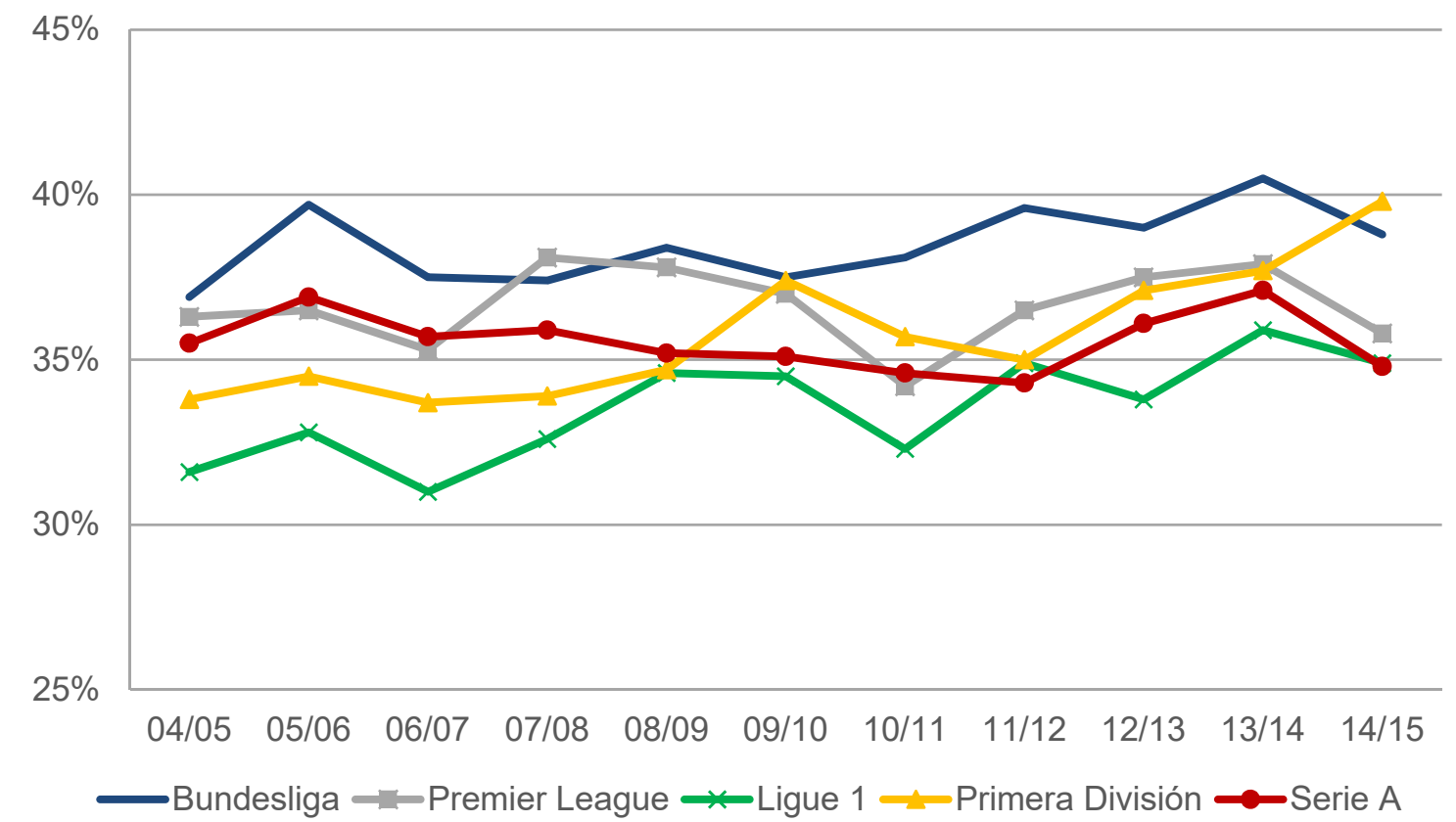

Figure 7: Share of points of the five best clubs across the five first European football leagues in the sample (Source: Own calculation).

\section{Investor presence in European football leagues}

To measure the interplay of financial fair play, investor presence in European football leagues, and competition, we need to define the term investor payments. Investor payments are payments made either by high-profile natural persons or legal entities that holds a significant share of the club's capital or 
high-profile natural persons or legal entities with no shareholdings in the club and no direct or indirect relationship to a sponsor of the club, credit or public sector institution. Investments made by these types of organizations are excluded intentionally because traditional sources of football club financing such as state-level subsidies, bank loans, or sponsorship payments are typically not regarded as investor payments. In a sense, we want to capture payments that potentially reflect a shock to the status quo, which are either driven by "sugar daddies" or other shareholders. Thus, only sponsorship payments by direct shareholders (e.g., Adidas AG, Allianz SE, and Audi AG at FC Bayern München) as well as sponsoring payments with unusual conditions in case they can be linked indirectly to a club's shareholder (Manchester City F.C., Paris Saint-Germain F.C.) are considered. We further exclude investments from anonymous or small investors (e.g., small loans by fans). In our setting, investor payments are mostly either loans by external parties, donations, or the investor's share in recapitalizations. In addition, we include purchases of equity stakes that have previously been owned by the football club itself. An overview of all investor payments can be found in Appendix A.

Unfortunately, information on investor payments to football clubs is not readily available, particularly due to low or non-existent disclosure requirements. Nevertheless, we extensively screen financial reports, press releases as well as newspaper articles (in the original language versions) to obtain data on investors, their ties to the clubs as well as their payments. In this regard, we benefit from the high significance of football in the media and among fans as there are many articles on investor presence as well as their (oftentimes suspected) payments to football clubs. When there is no official information on investor transactions available, we validate the data based on different sources. 


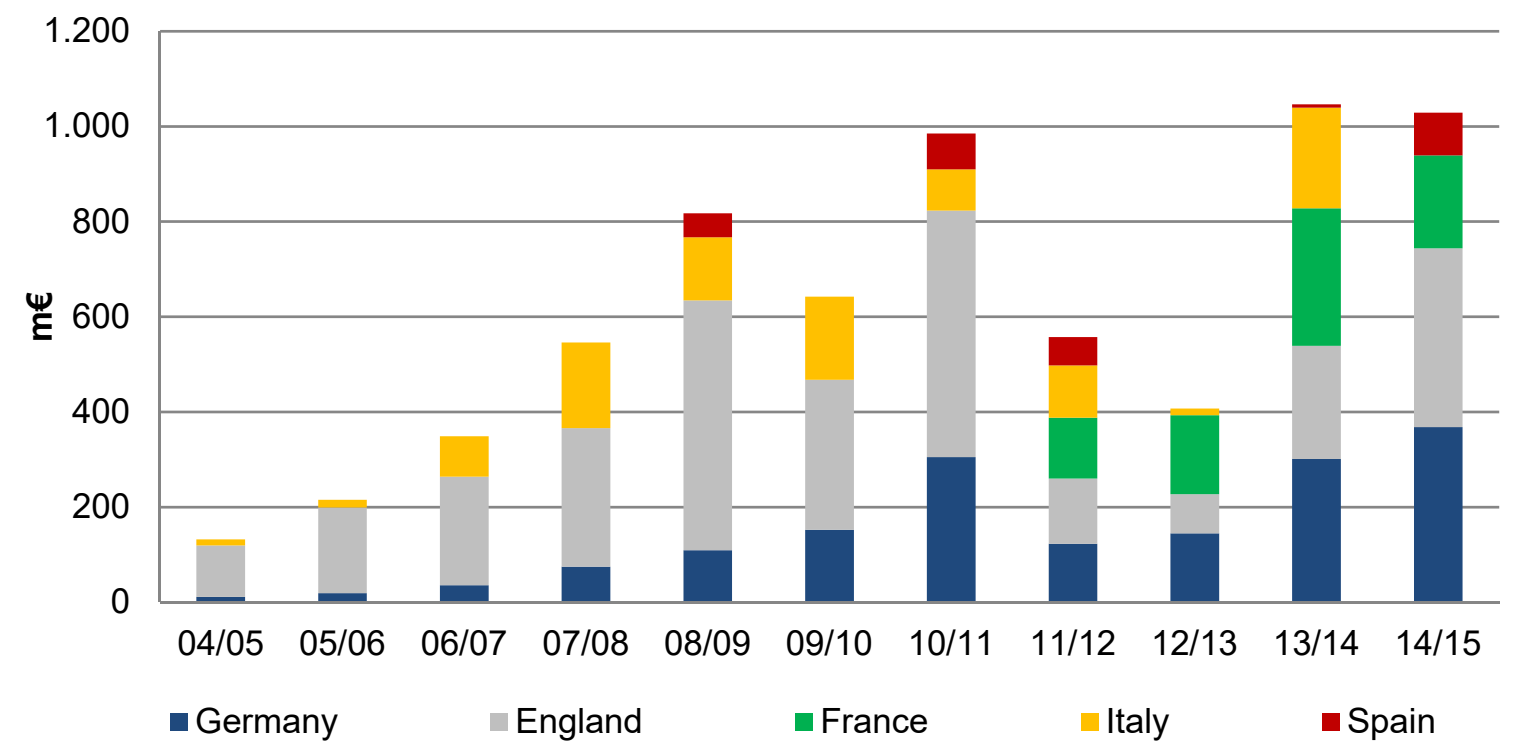

Figure 8: Investor payments to football clubs in major European leagues (Source: Own calculation).

Figure 8 depicts the sum of investor payments to football clubs from major European leagues. As can be seen in the figure, investor payments have become more important throughout the sample period, in particular outside England. While investor payments amounted to about $132 \mathrm{~m} €$ in 2004/2005 with the bulk of it being paid to English football clubs, they amounted to more than 1,029m€ in the 2014/2015 season with about equal parts going to English and German clubs. This trend is likely to continue as the UEFA has changed its financial fair play regulation so that football clubs may now attract investors more easily. Not surprisingly, $94 \%$ of the payments are made to clubs from the first league, potentially because these clubs appear more interesting to investors, for example because the brand of the club is more renowned. Finally, due to the so-called " $50+1$ " rule, German clubs usually must not be controlled by third parties and hence, have been less attractive to investors in the past.

\section{Other variables}

Besides measures of competition, we employ the following variables measured at the club-level. Player market values is the average of all players' market values (in $\mathrm{m} €$ ) of a given club in a given season. To calculate this variable, we obtain data for more than 60,000 players from www.tm.de, a website that provides extensive information on football clubs as well as their squads. ${ }^{5}$ On this webpage, player market values are estimated by experts and long-standing users. In doing so, www.tm.de arrives at

\footnotetext{
${ }^{5}$ The English equivalent is www.transfermarkt.co.uk.
} 
relatively precise estimates of a player's market value. ${ }^{6}$ In case there are missing market values for a given player in a given season, we set missing player market values to the lowest available player market value that is available for that club. To measure individual club performance, we rely on Points per match and Prob(win). Points per match is the average number of points scored in a given season. $\operatorname{Prob}($ win) is a team's share of wins in a given season. UEFA prize money, taken from official UEFA press releases, is the amount of money (in $\mathrm{m} €$ ) a club is awarded due to its participation and success in international tournaments. Squad size and Squad age, obtained from www.tm.de, are the number and the average age of all players in a given squad and season. Top4 league is a dummy variable which is set to one if a league's underlying national team was among the four best teams at the preceding world or European championships, and zero otherwise. First league is dummy variable which is set to one if the respective league is the first league in a given country, and zero otherwise. Finally, we measure absolute values of cash outflows (Transfer payments) and cash inflows (Transfer income) due to player transfers relative to lagged market values of a club's players. Again the data is obtained from www.tm.de.

In addition, we employ several variables measured at the league-level. The financial fair play (FFP) dummy is an indicator variable, which is set to one after 2013 and zero otherwise. ${ }^{7}$ The variable is supposed to capture implications of the introduction of the FFP regulation. Market value heterogeneity is the standard deviation of the clubs' average player market values in a given league and season (in $m €)$. Positive cash inflow denotes the fraction of clubs with at least one investor with an overall positive cash contribution to the club.

Finally, we also add a set of season dummies to all regression specifications to control for unobserved heterogeneity over time. In league-level (club-level) regressions, we also add league fixed (club) effects. In doing so, we can control for all time-invariant effects at the league- or club-levels, respectively.

\footnotetext{
${ }^{6}$ Gerhard, Mutz and Wagner (2014), for instance, show based on a sample 563 transfers during the 2012/2013 season that the correlation coefficient between player market values and actual transfer fees was 0.93 .

${ }^{7}$ In the license season 2013/14, for example, the „monitoring period” covers the reporting periods ending in 2012 and 2013, respectively (cf. Franck 2014).
} 


\section{FFP and competition in European football leagues}

\section{Investor presence and club competition}

First, we examine whether investor presence increases competition in national football leagues. To this end, we regress the three measures of competition on two measures of investor presence. On the one hand, we rely on Positive cash inflow, which denotes the fraction of clubs with at least one investor with an overall positive cash contribution to the club. On the other hand, we employ Cash flow heterogeneity, defined as the standard deviation of investor cash flows in a given league and season (in $\mathrm{m} €$ ). To control for unobserved heterogeneity, we add league and season fixed effects.

The results can be found in Table 1. Overall, we find a positive relation between the two measures of investor presence and competition. In two of the six models, the relation is also highly significant, even though we only look at within-league variation as we control for league fixed effects. The results are consistent with the view that investors can break up established structures and thereby increase competition. In addition to that, we also observe a strong negative relation between player market values and competition. 


\begin{tabular}{|c|c|c|c|c|c|c|}
\hline Dep. variable & $\begin{array}{c}\text { (Ia) } \\
\text { Theil index }\end{array}$ & $\begin{array}{l}\text { (Ib) } \\
\text { HICB }\end{array}$ & $\begin{array}{c}\text { (Ic) } \\
\text { C5ICB }\end{array}$ & $\begin{array}{c}\text { (IIa) } \\
\text { Theil index }\end{array}$ & $\begin{array}{l}\text { (IIb) } \\
\text { HICB }\end{array}$ & $\begin{array}{l}\text { (IIc) } \\
\text { C5ICB }\end{array}$ \\
\hline Top4 league & $\begin{array}{c}0.340 \\
(0.546)\end{array}$ & $\begin{array}{l}0.0612 \\
(0.953)\end{array}$ & $\begin{array}{c}0.621 \\
(2.111)\end{array}$ & $\begin{array}{c}0.399 \\
(0.528)\end{array}$ & $\begin{array}{c}0.223 \\
(0.858)\end{array}$ & $\begin{array}{c}1.104 \\
(1.996)\end{array}$ \\
\hline Market value heterogeneity & $\begin{array}{c}-1.980 * * * \\
(0.495)\end{array}$ & $\begin{array}{c}-1.529 * * \\
(0.500)\end{array}$ & $\begin{array}{c}-4.309 * * * \\
(1.106)\end{array}$ & $\begin{array}{c}-1.823 * * * \\
(0.542)\end{array}$ & $\begin{array}{l}-1.110 * \\
(0.599)\end{array}$ & $\begin{array}{l}-2.947 \\
(1.681)\end{array}$ \\
\hline Positive cash inflow & $\begin{array}{c}2.883 \\
(1.819)\end{array}$ & $\begin{array}{l}8.138 * * \\
(2.620)\end{array}$ & $\begin{array}{c}22.10 * * * \\
(6.596)\end{array}$ & & & \\
\hline Cash flow heterogeneity & & & & $\begin{array}{c}0.00205 \\
(0.00628) \\
\end{array}$ & $\begin{array}{c}0.0113 \\
(0.0125) \\
\end{array}$ & $\begin{array}{r}-0.0228 \\
(0.0498) \\
\end{array}$ \\
\hline Season fixed effects & yes & yes & yes & yes & yes & yes \\
\hline League fixed effects & yes & yes & yes & yes & yes & yes \\
\hline Observations & 90 & 90 & 90 & 90 & 90 & 90 \\
\hline $\mathrm{R}^{2}$ & 0.913 & 0.709 & 0.685 & 0.910 & 0.683 & 0.660 \\
\hline
\end{tabular}

Table 1: The dependent variables are different measures for the level of competition in major European football leagues (Section 4). One observation corresponds to one league in a given year. First League is a dummy set to one for the highest football leagues and zero otherwise. Top4 league is a dummy variable which is

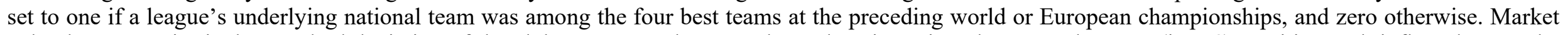
value heterogeneity is the standard deviation of the clubs' average player market values in a given league and season (in m€). Positive cash inflow denotes the

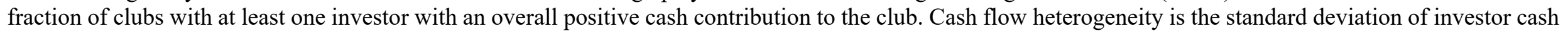

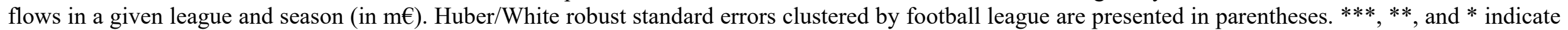
significance at the 1\%-, 5\%-, and 10\%-levels, respectively. 


\section{Financial fair play and club competition}

In this section, we examine the determinants of club competition in European football leagues. To this end, we regress the three measures of league inequality on an interaction of the First League indicator and the financial fair play (FFP) indicator, which is set to one after 2013 and zero otherwise. We also add a set of control variables and league and season fixed effects to control for time-invariant unobserved heterogeneity at the league-level. Standard errors are clustered by football league.

The rationale behind the interaction of the First League and FFP indicators is to come up with a differences-in-differences setting, where first leagues, in which participation in international tournaments is much more likely than in second leagues, are the treatment group. Therefore, second leagues are the control group. The period before the introduction of the FFP regulation is the pretreatment period, while the period after FFP has been introduced is the post-treatment period. Thus, the coefficient for the interaction between the treatment and the FFP indicators corresponds to the differences-in-differences effect.

When performing a differences-in-differences analysis, it is important to ensure that the parallel trends assumption holds (e.g., Roberts \& Whited 2012). To this end, we perform a graphical analysis of the development of the three measures of competition over time. The results can be found in Figures 9 to 11. As can be seen by looking at the figures, the level of competition remains relatively flat until 2012 both in major European first and second leagues, respectively. However, beginning in 2012, when FFP regulation was put into mandate, competition dropped significantly in 2012 in the treatment group, i.e., the first leagues, while it remained virtually unchanged in the second leagues. From the figures, it is also interesting to see that competition is generally lower in the first European football leagues. When performing differences-in-differences analysis, this pattern does not harm econometric analysis, as the differences-in-differences estimator accounts for this. Thus, from the graphical analysis in Figures 11 to 13, we conclude that the parallel trends assumption is not violated and that the differences-in-differences estimates represents a viable methodology to estimate the effects of the FFP regulation on competition. 


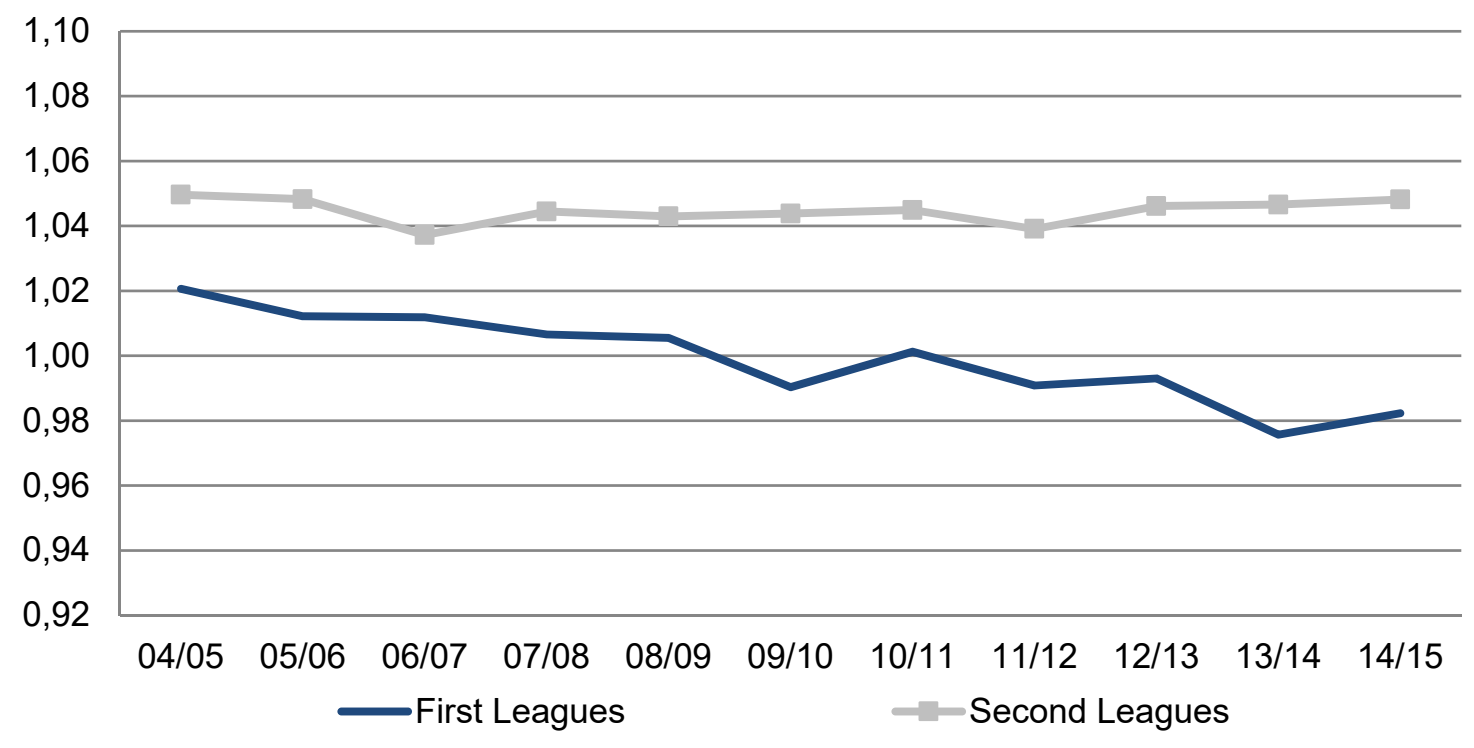

Figure 9: Theil index for European football leagues (Source: Own calculation).

The results can be found in Models I in Table 2. The table is restricted to observations after 2009 to arrive at a symmetric time window around the introduction of FFP. We observe that player market value heterogeneity is negatively related to competition: The more unequal the player market values of a league's clubs, the less suspenseful a league will be, both in the short-run (Theil index) and long-run (HICB, C5ICB). In contrast, the presence of investors, approximated by Positive cash inflow, which denotes the fraction of clubs with at least one investor with an overall positive cash contribution to the club, is positively correlated to competition. Thus, similar to venture capital, investors may break up established structures and increase competition. 

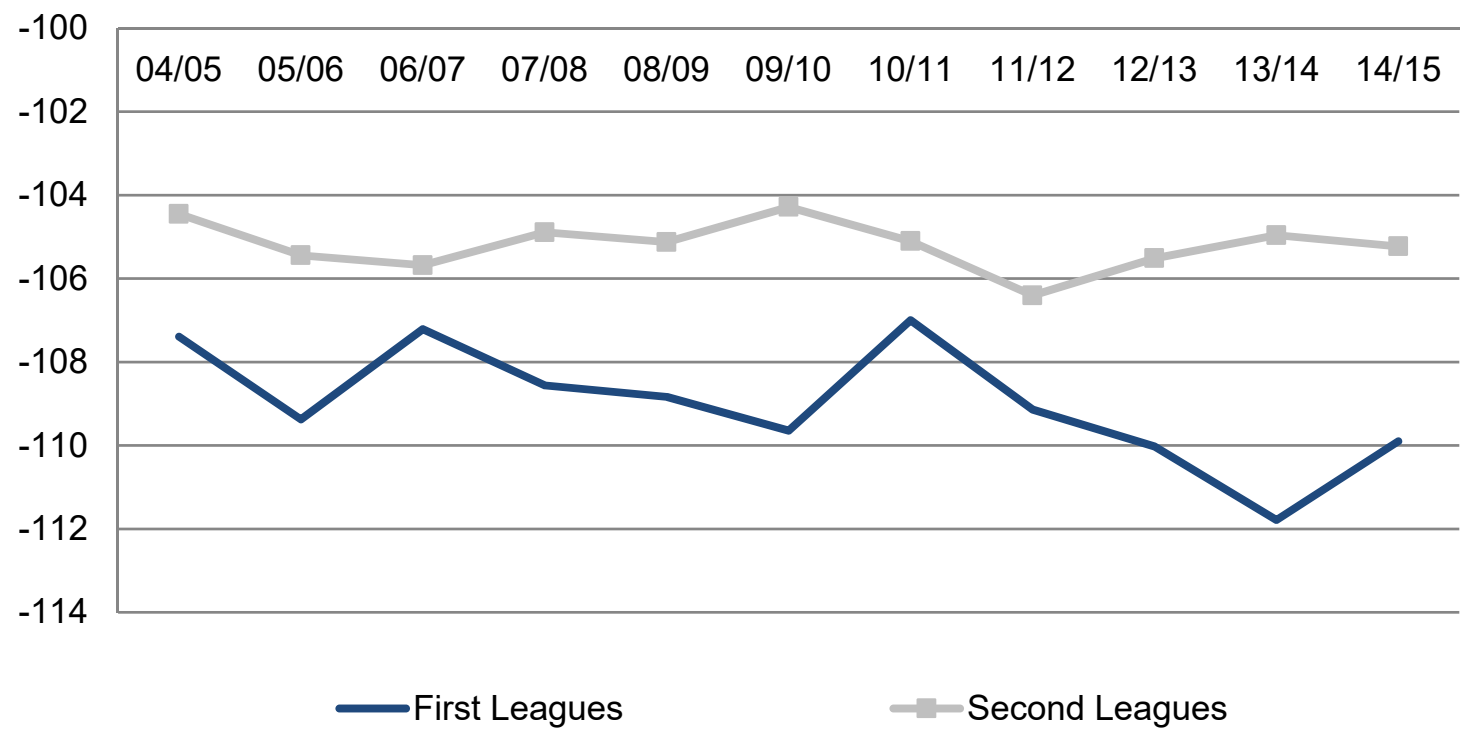

Figure 10: Negative HICB for European football leagues (Source: Own calculation).

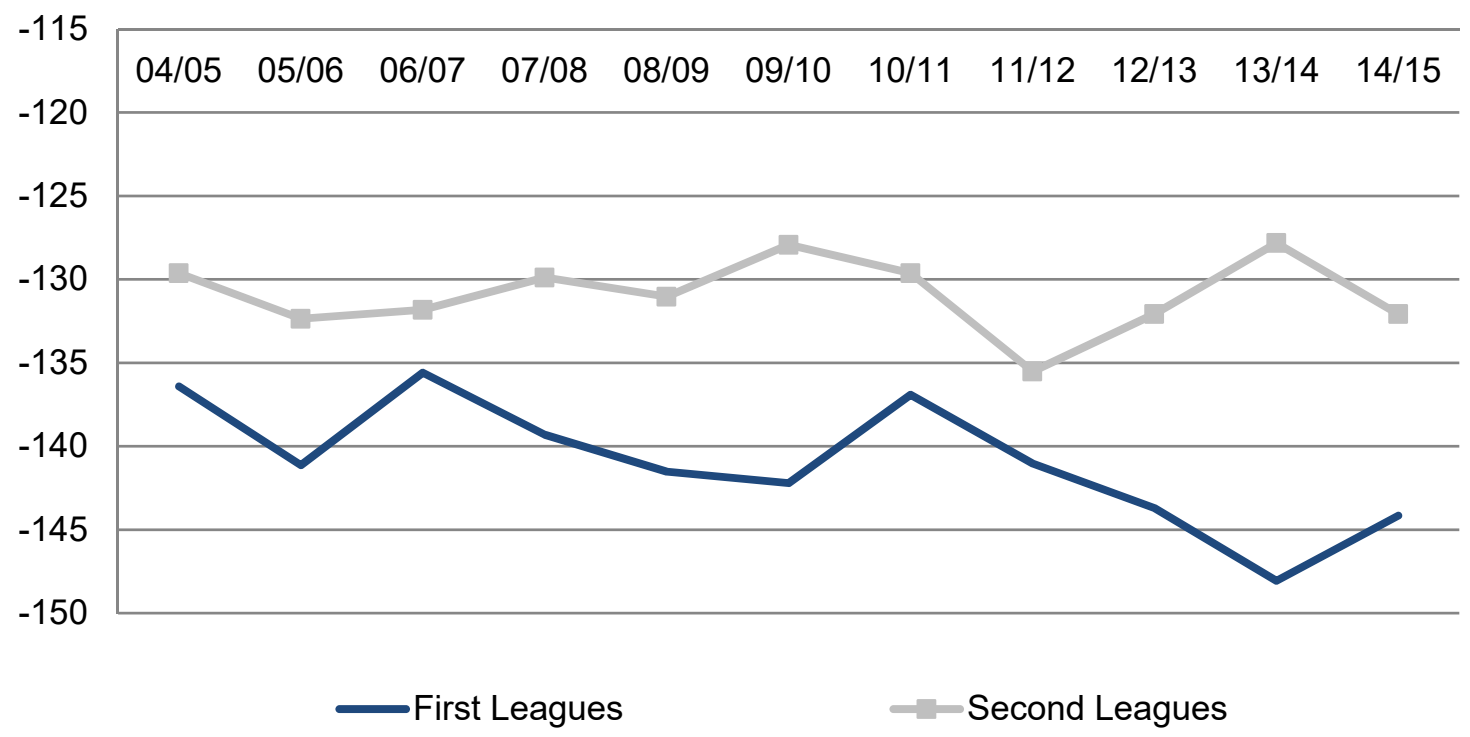

Figure 11: Negative C5ICB for European football leagues (Source: Own calculation). 


\begin{tabular}{|c|c|c|c|c|c|c|}
\hline Dep. variable & $\begin{array}{c}\text { (Ia) } \\
\text { Theil index }\end{array}$ & $\begin{array}{l}(\mathrm{Ib}) \\
\mathrm{HICB}\end{array}$ & $\begin{array}{l}\text { (Ic) } \\
\text { C5ICB }\end{array}$ & $\begin{array}{c}\text { (IIa) } \\
\text { Theil index }\end{array}$ & $\begin{array}{l}\text { (IIb) } \\
\text { HICB }\end{array}$ & $\begin{array}{l}\text { (IIc) } \\
\text { C5ICB }\end{array}$ \\
\hline Top4 league & $\begin{array}{c}0.617 \\
(0.719)\end{array}$ & $\begin{array}{c}0.258 \\
(1.193)\end{array}$ & $\begin{array}{l}-1.072 \\
(2.947)\end{array}$ & $\begin{array}{c}1.162 \\
(0.768)\end{array}$ & $\begin{array}{c}1.338 \\
(0.973)\end{array}$ & $\begin{array}{c}2.107 \\
(2.542)\end{array}$ \\
\hline Market value heterogeneity & $\begin{array}{l}-0.794 \\
(0.507)\end{array}$ & $\begin{array}{l}-0.437 \\
(0.929)\end{array}$ & $\begin{array}{l}-0.941 \\
(1.896)\end{array}$ & $\begin{array}{l}-0.616 \\
(0.686)\end{array}$ & $\begin{array}{l}-0.112 \\
(1.219)\end{array}$ & $\begin{array}{l}-0.581 \\
(2.705)\end{array}$ \\
\hline Positive cash inflow & $\begin{array}{l}-0.374 \\
(1.962)\end{array}$ & $\begin{array}{l}13.30 * * \\
(4.620)\end{array}$ & $\begin{array}{l}36.29 * * \\
(12.64)\end{array}$ & $\begin{array}{l}-2.395 \\
(2.472)\end{array}$ & $\begin{array}{c}9.306 \\
(5.317)\end{array}$ & $\begin{array}{c}24.67 \\
(15.12)\end{array}$ \\
\hline First League * FFP & $\begin{array}{c}-1.435 * \\
(0.714)\end{array}$ & $\begin{array}{l}-2.866 * \\
(1.286)\end{array}$ & $\begin{array}{l}-9.003 * \\
(4.049)\end{array}$ & & & \\
\hline First League * FFP (2012) & & & & $\begin{array}{c}-1.479 * \\
(0.770)\end{array}$ & $\begin{array}{l}-2.887 * \\
(1.415)\end{array}$ & $\begin{array}{c}-7.630 * \\
(3.866)\end{array}$ \\
\hline Season fixed effects & yes & yes & yes & yes & yes & yes \\
\hline $\begin{array}{l}\text { League fixed effects } \\
\text { Observations }\end{array}$ & $\begin{array}{l}\text { yes } \\
50\end{array}$ & $\begin{array}{l}\text { yes } \\
50\end{array}$ & $\begin{array}{c}\text { yes } \\
50\end{array}$ & $\begin{array}{c}\text { yes } \\
50\end{array}$ & $\begin{array}{l}\text { yes } \\
50\end{array}$ & $\begin{array}{l}\text { yes } \\
50\end{array}$ \\
\hline $\mathrm{R}^{2}$ & 0.968 & 0.780 & 0.736 & 0.968 & 0.778 & 0.720 \\
\hline
\end{tabular}

Table 2: The dependent variables are different measures for the level of competition in major European football leagues (Section 4). One observation corresponds to one league in a given year. The table is restricted to observations after 2009. The financial fair play (FFP) dummy is an indicator variable, which is set to one after 2013 and zero otherwise. Alternatively, we also set the variable to one after 2012 only (Models II). First League is a dummy set to one for the highest football leagues and zero otherwise. Top4 league is a dummy variable which is set to one if a league's underlying national team was among the four best teams at the preceding world or European championships, and zero otherwise. Market value heterogeneity is the standard deviation of the clubs' average player market values in a given league and season (in $\mathrm{m} €$ ). Positive cash inflow denotes the fraction of clubs with at least one investor with an overall positive cash contribution to the club. Huber/White robust standard errors clustered by football league are presented in parentheses. ***, **, and * indicate significance at the 1\%-, 5\%-, and 10\%levels, respectively. 


\begin{tabular}{|c|c|c|c|c|c|c|c|}
\hline Dep. variable & $\begin{array}{c}\text { (I) } \\
\text { HICB }\end{array}$ & $\begin{array}{l}\text { (IIa) } \\
\text { HICB }\end{array}$ & $\begin{array}{c}\text { (IIb) } \\
\text { HICB }\end{array}$ & $\begin{array}{l}\text { (IIIa) } \\
\text { HICB }\end{array}$ & $\begin{array}{l}\text { (IIIb) } \\
\text { HICB }\end{array}$ & $\begin{array}{l}\text { (IVa) } \\
\text { HICB }\end{array}$ & $\begin{array}{l}\text { (IVb) } \\
\text { HICB }\end{array}$ \\
\hline Positive cash inflow & & $\begin{array}{l}13.48^{* *} \\
(4.271)\end{array}$ & $\begin{array}{l}13.33^{* *} \\
(4.722)\end{array}$ & $\begin{array}{c}10.54 * * * \\
(2.905)\end{array}$ & $\begin{array}{c}13.85 * * * \\
(3.914)\end{array}$ & $\begin{array}{l}12.31 * \\
(5.546)\end{array}$ & \\
\hline Cash flow heterogeneity & & & & & & & $\begin{array}{c}0.0484 * \\
(0.0221)\end{array}$ \\
\hline First League * FFP (2013) & $\begin{array}{l}-2.385^{*} \\
(1.088)\end{array}$ & $\begin{array}{c}-2.816 * * \\
(1.228)\end{array}$ & $\begin{array}{l}-2.870^{*} \\
(1.302)\end{array}$ & & & & \\
\hline Foreign test games & & $\begin{array}{c}0.768 \\
(6.408)\end{array}$ & & & & & \\
\hline $\mathrm{SD}$ (Foreign test games) & & & $\begin{array}{l}-0.0559 \\
(0.960)\end{array}$ & & & & \\
\hline First League * Placebo & & & & $\begin{array}{c}\mathbf{0 . 1 2 3} \\
(\mathbf{1 . 3 2 9})\end{array}$ & $\begin{array}{l}-\mathbf{- 0 . 6 6 5} \\
(2.192)\end{array}$ & & \\
\hline Positive cash inflow * FFP & & & & & & $\begin{array}{l}-1.680 \\
(2.216)\end{array}$ & \\
\hline Cash flow heterogeneity * FFP & & & & & & & $\begin{array}{c}-0.072 * \\
(0.039)\end{array}$ \\
\hline Season fixed effects & Yes & Yes & Yes & Yes & Yes & Yes & Yes \\
\hline League fixed effects & Yes & Yes & Yes & Yes & Yes & Yes & Yes \\
\hline Controls & No & Yes & Yes & Yes & Yes & Yes & Yes \\
\hline Observations & 110 & 50 & 50 & 60 & 50 & 50 & 50 \\
\hline $\mathrm{R}^{2}$ & 0.687 & 0.780 & 0.780 & 0.718 & 0.727 & 0.742 & 0.743 \\
\hline
\end{tabular}

Table 3: The dependent variable is the HICB measure that captures competition in major European football leagues (Section 4). One observation corresponds to one league in a given year. In Models II and IV, the table is restricted to observations after 2009. In Model IIIa (IIIb), the sample is restricted to observations before 2011 (2010). The financial fair play (FFP) dummy is an indicator variable, which is set to one after 2013 and zero otherwise. First League is a dummy set to one for the highest football leagues and zero otherwise. Top4 league is a dummy variable which is set to one if a league's underlying national team was among the four best teams at the preceding world or European championships, and zero otherwise. Market value heterogeneity is the standard deviation of the clubs' average player market values in a given league and season (in $\mathrm{m} €$ ). Positive cash inflow denotes the fraction of clubs with at least one investor with an overall positive cash contribution to the club. Cash flow heterogeneity is the standard deviation of investor cash flows in a given league and season (in $m €$ ). Foreign test games reflects the share of football clubs in a given league and season that performed test games against teams from other countries. SD(Foreign test games) is the standard deviation of the number of test games against foreign teams before the start of the season, calculated per league and season. Models III perform placebo tests. The Placebo dummy is set to one after 2009 (2008) in Model IIIa (IIIb), and zero otherwise. Huber/White robust standard errors clustered by football league are presented in parentheses. $* * *, * *$, and $*$ indicate significance at the $1 \%-, 5 \%$-, and $10 \%$-levels, respectively. 
Most importantly, however, we find that the coefficient for the interaction of the FFP and the First League indicators are negative and statistically different from zero in two of the three models. ${ }^{8}$ When we replace the FFP indicator with another dummy variable that is already set to one after 2012 (i.e., after early effects of the financial fair play regulation became relevant) and zero otherwise, we obtain similar results (Models II). The result are thus consistent with the view that FFP has led to a reduction in competitive balance in European football leagues. ${ }^{9}$

In Table 3, we examine the robustness of the results. First, we show that the results are robust to the exclusion of control variables as well as extending the sample period to all available years (Model I). ${ }^{10}$ Moreover, in Appendix B we perform additional robustness tests based on other measures of competitive balance. Also, if we use the FFP (2012) dummy as an alternative starting point we get similar results (not reported). Second, in Models II, we additionally control for the fraction of football clubs that performed test games against foreign clubs before the start of the season (Foreign test games) and the standard deviation of the number of test games against foreign teams before the start of the season, calculated per league and season ( $\mathrm{SD}$ (Foreign test games)). Data for these variables is manually collected from www.scorespro.com, a provider of extensive information on all types of football matches. ${ }^{11}$ These variables are supposed to capture the extent to which clubs can extract revenues from transnational popularity. Ultimately, these measures are supposed to control for the amount of money a club can generate in a world of globalized football markets because we expect that transnational fans (revenues) are positively correlated with test games against foreign opponents. ${ }^{12}$ In this way we control for unobserved heterogeneity which might drive our results. As the introduction of FFP went along with

\footnotetext{
${ }^{8}$ Note that the model does not include the FFP and the First League dummies individually. This is because these variables are captured by the league and season fixed effects.

${ }^{9}$ It is not completely clear when FFP regulation became actually binding. We would argue that clubs could have expected that compliance with the rules was important in the 2013/2014 season. In February 2014, the UEFA announced that it would investigate the financial status of 76 clubs in more detail due to potential violation of the new regulation. These clubs had to provide the UEFA with additional financial information. Finally, in May 2014, the UEFA settled with nine of those clubs. In this regard, FC Zenit Saint Petersburg, Paris Saint-German F.C., and Manchester City F.C. agreed to pay $132 \mathrm{~m} €$ in fines (which may partly be returned after compliance with the rules), transfer spending restrictions, and salary caps. Therefore, UEFA FFP regulation is likely to have affected footballs clubs and competitive balance during the 2013/2014 season.

${ }^{10}$ In Appendix B, we perform additional robustness tests based on other measures of competitive balance.

${ }^{11}$ On average, across first and second leagues, we find that teams play against other clubs from 2.19 countries. $64 \%$ of the teams play test games against foreign clubs.

${ }^{12}$ Ideally, one would like to obtain data on revenues or the size of the fan base. However, this data is not available for most clubs.
} 
more intensive intercontinental marketing activities by European football clubs and, as a consequence, with increasing revenues from TV-rights and merchandising, it could well be, that this has created additional imbalances in the football leagues. However, our results are robust to the inclusion of these variables. ${ }^{13}$

Third, in Models III, we perform placebo tests to show that our FFP dummies do not capture other underlying time trends. Therefore, in Model IIIa (IIIb), we restrict the sample to observations before 2011 (2010), i.e., before the financial fair play treatment and set the placebo dummy to one after 2009 (2008), and zero otherwise. Across all specifications, we do not observe a consistent pattern for the interactions of the placebo dummy and the first league indicator, suggesting that the results do not hold for other time windows. Overall, the evidence in Table 3 is thus in line with the view that FFP has reduced competition in European football leagues.

In Models IV, we additionally test more directly whether the positive impact of investor payments on competition is reduced after the introduction of FFP. To this end, we interact two measures of investor presence with the FFP indicator. The two measures of investor presence are Positive cash inflow and Cash flow heterogeneity, defined as the standard deviation of investor cash flows in a given league and season (in $\mathrm{m} €$ ). Across both models, we find that investor presence is still positively correlated with competition. This effect, however, is reduced after the introduction of FFP, as indicated be the negative interaction terms in all models. ${ }^{14}$

We further examine another channel through which FFP reduces competition. Therefore, we regress player market value heterogeneity on the interacted First League and FFP indicators, respectively. The results can be found in Table 4. The table suggests that FFP leads to an increase in the dispersion of player market values in the first football leagues. The result is consistent with the view that FFP makes European football leagues even less equilibrated and tends to freeze current hierarchies.

\footnotetext{
${ }^{13}$ The results are even stronger when we examine transcontinental instead of international friendlies only.

${ }^{14}$ The robustness of the results in Models IV is provided in Appendix C.
} 


\begin{tabular}{lcc}
\hline \hline Dep. variable & $\begin{array}{c}(\mathrm{I}) \\
\text { Market value } \\
\text { heterogeneity }\end{array}$ & $\begin{array}{c}\text { (II) } \\
\text { Market value } \\
\text { heterogeneity }\end{array}$ \\
\hline Top4 league & -0.00375 & 0.0256 \\
& $(0.192)$ & $(0.210)$ \\
Cash flow heterogeneity & & $-0.00592^{*}$ \\
& & $(0.00266)$ \\
First League * FFP & $\mathbf{0 . 5 1 7 *}$ & $\mathbf{0 . 6 0 3 * *}$ \\
& $\mathbf{( 0 . 2 3 7 )}$ & $\mathbf{( 0 . 2 5 0 )}$ \\
\hline Season fixed effects & Yes & Yes \\
League fixed effects & Yes & 50 \\
Observations & 50 & 0.980 \\
$\mathrm{R}^{2}$ & 0.980 & Yes \\
\hline \hline
\end{tabular}

Table 4: The dependent variable is the heterogeneity of player market values in a given league and season. It is defined as the standard deviation of the clubs' average player market values in a given league and season (in $\mathrm{m} €$ ). One observation corresponds to one league in a given year. The table is restricted to observations after 2009. The financial fair play (FFP) dummy is an indicator variable, which is set to one after 2012 and zero otherwise. First League is a dummy set to one for the highest football leagues and zero otherwise. Top4 league is a dummy variable which is set to one if a league's underlying national team was among the four best teams at the preceding world or European championships, and zero otherwise. Cash flow heterogeneity is the standard deviation of investor cash flows in a given league and season (in $\mathrm{m} €$ ). Huber/White robust standard errors clustered by football league are presented in parentheses. ${ }^{* *}, *^{* *}$, and $*$ indicate significance at the $1 \%-, 5 \%-$, and $10 \%-l e v e l s$, respectively.

\section{The freezing effect of FFP}

In this section, we show that FFP strengthens the link between past success in the league and player transfers in the upcoming season. Thereby, it ultimately freezes existent hierarchies and reduces competition. To this end, we regress absolute values of cash outflows due to player transfers relative to lagged market values of a club's players on two proxies for a club's success in the last season interacted with the FFP dummy. The two measures of past club success are the average points per match and the probability of a victory. In addition, we control for the average player market value per club, the size and the average age of the squad, cash inflows by player sales in the transfer market relative to the lagged market value of the squad, and the amount of UEFA prize money awarded in the previous season relative to the lagged market value of the squad. Results for club-level regressions can be found in Table 5. The table is based on first league observations only. To control for unobserved heterogeneity, we now include club and season fixed effects. Besides relative transfer income, all independent club-level variables are lagged by one season. Standard errors are clustered at the club-level.

We find that, relative to the market value of the squad, clubs with more valuable players and greater squads invest less money into new players. In contrast, teams with higher proceeds from player sales 
invest more money in the purchase of new players. Interestingly, clubs that had been more successful in the past season also spend higher amounts of money on new players, as indicated by the positive and highly significant coefficients for points per match and probability of a victory.

Most importantly, however, we observe positive coefficients for the interaction terms of past success and the FFP dummy. The coefficients are significant at the 5\% level for the interaction based on the winning probability and they are close to conventional significance levels for the points per match variable. Thus, after the introduction of the FFP regulation, the link between past success and future spending on new players became stronger. Thereby, FPP benefits already successful clubs and makes it more difficult for less successful teams to spend more money on new players to improve the squad, which, in turn, results in lower competition. ${ }^{15}$ To sum up, all our results corroborate the criticism that FFP makes European football leagues even less equilibrated and tends to freeze current hierarchies.

\begin{tabular}{lcccc}
\hline \hline Dep. variable & $\begin{array}{c}(\mathrm{Ia}) \\
\text { Transfer } \\
\text { payments }\end{array}$ & $\begin{array}{c}(\mathrm{Ib}) \\
\text { Transfer } \\
\text { payments }\end{array}$ & $\begin{array}{c}\text { (IIa) } \\
\text { Transfer } \\
\text { payments }\end{array}$ & $\begin{array}{c}\text { (IIb) } \\
\text { Transfer } \\
\text { payments }\end{array}$ \\
\hline Player market value & $-0.0443^{* *}$ & $-0.0505^{* *}$ & $-0.0428^{* *}$ & $-0.0480^{* *}$ \\
& $(0.0193)$ & $(0.0201)$ & $(0.0206)$ & $(0.0210)$ \\
Squad size & $-0.00756^{* *}$ & $-0.00769^{* *}$ & $-0.00747^{* *}$ & $-0.00753^{* *}$ \\
& $(0.00324)$ & $(0.00327)$ & $(0.00331)$ & $(0.00331)$ \\
Squad age & -0.00600 & -0.00213 & -0.00613 & -0.00214 \\
& $(0.0142)$ & $(0.0139)$ & $(0.0141)$ & $(0.0137)$ \\
Transfer income & -0.0446 & -0.0406 & -0.0475 & -0.0456 \\
& $(0.119)$ & $(0.120)$ & $(0.120)$ & $(0.121)$ \\
UEFA prize money & & & -0.124 & -0.219 \\
& & & $(0.200)$ & $(0.181)$ \\
\hline Points per match & $0.0706^{*}$ & & $0.0709^{*}$ & \\
& $(0.0412)$ & & $(0.0408)$ & \\
Points per match * FFP & $\mathbf{0 . 1 1 0}$ & $\mathbf{0 . 1 1 0}$ & \\
& $\mathbf{( 0 . 0 6 8 9 )}$ & & $\mathbf{( 0 . 0 6 8 4 )}$ & \\
Prob(win) & & $0.460^{*}$ & & $0.489^{* *}$ \\
& & $(0.239)$ & & $(0.231)$ \\
Prob(win) * FFP & & $\mathbf{0 . 4 3 3 * *}$ & & $\mathbf{0 . 4 2 6 * *}$ \\
& & $\mathbf{( 0 . 1 9 3 )}$ & & $(\mathbf{0 . 1 9 1 )}$ \\
\hline Season fixed effects & Yes & Yes & Yes & Yes \\
Club fixed effects & Yes & Yes & Yes & Yes \\
Observations & 482 & 482 & 482 & 482 \\
R-squared & 0.624 & 0.627 & 0.624 & 0.628 \\
\hline \hline
\end{tabular}

Table 5: The dependent variable is the absolute value of transfer payments of a given football club in a given league and year relative to the lagged market value of the squad. One observation corresponds to one value per club and season. The table is restricted to observations after 2009 and to first league observations only. The financial fair play (FFP) dummy is an indicator variable, which is set to one after 2013 and zero otherwise. Points per match is the average number of points scored in a given season.

\footnotetext{
${ }^{15}$ The results become stronger when one replaces the FFP dummy with the FFP (2012) dummy.
} 
Prob(win) is a team's share of wins in a given season. Player market value is the average of all players' market values (in $\mathrm{m} €$ ) of a given club in a given season. Squad size and Squad age are the number and the average age of all players in a given squad and season. Transfer income is cash inflows due to player transfers relative to the lagged market value of a club's players. UEFA prize money, taken from official UEFA press releases, is the amount of money (in $\mathrm{m} €$ ) a club is awarded due to its participation and success in international tournaments. All independent variables are lagged by one period. Huber/White robust standard errors clustered by club are presented in parentheses. ***,**, and * indicate significance at the $1 \%$-, $5 \%$-, and $10 \%$-levels, respectively.

In Table 6, we show that the results are also robust to controlling for investor payments. For example, it could be that successful clubs retrieve more investor payments, which could spuriously result in more transfer cash outflows in those clubs. To mitigate this concern, we also control for contemporaneous investor payments to a given club in a given season. Not surprisingly, we observe that clubs that receive more investor payments spend more money on new players. Most importantly, however, we still find that the link between past success and future purchases of new players is stronger after the introduction of FFP, even after controlling for investor payments. 


\begin{tabular}{lcccc}
\hline \hline Dep. variable & $\begin{array}{c}\text { (Ia) } \\
\text { Transfer } \\
\text { payments }\end{array}$ & $\begin{array}{c}\text { (Ib) } \\
\text { Transfer } \\
\text { payments }\end{array}$ & $\begin{array}{c}\text { (IIa) } \\
\text { Transfer } \\
\text { payments }\end{array}$ & $\begin{array}{c}\text { (IIb) } \\
\text { Transfer } \\
\text { payments }\end{array}$ \\
\hline Player market value & $-0.0460^{* *}$ & $-0.0521^{* *}$ & $-0.0447^{*}$ & $-0.0497^{* *}$ \\
& $(0.0213)$ & $(0.0219)$ & $(0.0228)$ & $(0.0230)$ \\
Squad size & $-0.00769^{* *}$ & $-0.00780^{* *}$ & $-0.00760^{* *}$ & $-0.00764^{* *}$ \\
& $(0.00333)$ & $(0.00335)$ & $(0.00341)$ & $(0.00341)$ \\
Squad age & -0.00641 & -0.00254 & -0.00652 & -0.00254 \\
& $(0.0144)$ & $(0.0141)$ & $(0.0143)$ & $(0.0139)$ \\
Transfer income & -0.0367 & -0.0330 & -0.0395 & -0.0382 \\
& $(0.125)$ & $(0.126)$ & $(0.127)$ & $(0.128)$ \\
UEFA prize money & & & -0.108 & -0.203 \\
& & & $(0.207)$ & $(0.190)$ \\
\hline Investor payments & 0.0121 & 0.0116 & 0.0117 & 0.0106 \\
& $(0.0165)$ & $(0.0164)$ & $(0.0168)$ & $(0.0166)$ \\
\hline Points per match & $0.0690^{*}$ & & $0.0693 *$ & \\
& $(0.0413)$ & & $(0.0409)$ & \\
Points per match * FFP & $\mathbf{0 . 1 1 4}$ & $\mathbf{0 . 1 1 4}$ & \\
& $\mathbf{( 0 . 0 7 1 8 )}$ & & $\mathbf{( 0 . 0 7 1 4 )}$ & \\
Prob(win) & & $0.457^{*}$ & & $0.486^{* *}$ \\
Prob(win) * FFP & & $(0.238)$ & & $(0.230)$ \\
& & $\mathbf{0 . 4 4 3 * *}$ & & $\mathbf{0 . 4 3 7 * *}$ \\
\hline Season fixed effects & Yes & Yes & Yes & Yes \\
Club fixed effects & Yes & Yes & Yes & Yes \\
Observations & 482 & 482 & 482 & 482 \\
R-squared & 0.625 & 0.628 & 0.625 & 0.629 \\
\hline \hline
\end{tabular}

Table 6: The dependent variable is the absolute value of transfer payments of a given football club in a given league and year relative to the lagged market value of the squad. One observation corresponds to one value per club and season. The table is restricted to observations after 2009 and to first league observations only. The financial fair play (FFP) dummy is an indicator variable, which is set to one after 2013 and zero otherwise. Points per match is the average number of points scored in a given season. Prob(win) is a team's share of wins in a given season. Player market value is the average of all players' market values (in $\mathrm{m} €$ ) of a given club in a given season. Squad size and Squad age are the number and the average age of all players in a given squad and season. Transfer income is cash inflows due to player transfers relative to the lagged market value of a club's players. UEFA prize money, taken from official UEFA press releases, is the amount of money (in $\mathrm{m} €$ ) a club is awarded due to its participation and success in international tournaments. Investor payments are investor payments to a given club in a given season (Section 4). All independent variables are lagged by one period. Huber/White robust standard errors clustered by club are presented in parentheses. ***, **, and * indicate significance at the $1 \%-$, $5 \%$-, and 10\%-levels, respectively.

\section{Summary and Discussion}

In 2010, the UEFA approved new financial fair play (FFP) regulations to improve the financial health of European football clubs. In this paper, however, we show that there may be unintended consequences of the new FFP regulations. Based on a novel dataset of European football clubs, we find results that are consistent with the view that FFP has further amplified competitive imbalance. This is likely because FFP may raise some barriers against the entrance of new investors. Accordingly, we present evidence that, after the introduction of FFP, former season's winners are correlated with greater budget shares in 
the upcoming season. Also, the positive correlation between the presence of football investors and competition is lower after the introduction of FFP. Overall, our results are consistent with the view that FFP tends to make European football leagues less equilibrated and to freeze current hierarchies. It fits into this picture that according to some authors FFP rules may be violating European Union antitrust laws (e.g., Kaplan, 2015).

Thus, our study may have several implications. As competition in European football leagues has decreased considerably over the past decade, the UEFA might want to reexamine its FFP regulation. Actually, simply withdrawing the FFP rules may not prove helpful, because the financial health of European football clubs might quickly deteriorate again. Therefore, the UEFA could both legislate rules that foster competition among European football clubs and search for alternative ways of ensuring financial stability.

On the one hand, UEFA's break-even rule might not be helpful to increase competition as it limits certain investor cash flows. Furthermore, UEFA prize money, which is awarded to only a small fraction of clubs in a given league, has increased tremendously over the past decade (Figure 2). Thereby, it is likely that the current distribution system of prize money has further concentrated current hierarchies in and across European football leagues. Therefore, the UEFA might want to consider a different distribution mechanism. In this regard, D’Andrea \& Masciandaro (2016) also suggests the redistribution of revenues or revenue sharing.

On the other hand, to ensure financial stability even in case the break-even rule might have been withdrawn or alleviated, the UEFA could further improve financial oversight and transparency in terms of reporting quality. Furthermore, similar to stock companies, football clubs could be well-advised to install audit committees that oversee their clubs or to generally improve their governance.

In light of these developments, national football associations may also be well advised to search for alternative ways of maintaining or improving both the attractiveness as well as the international competitiveness of their respective leagues. For example, they could look for new ways in order to increase the overall value of television rights. Thereby, national football clubs could benefit from additional cash inflows, which would make them more competitive internationally. In addition, national 
rules preventing new investors from entering the scene (as the so called 50+1 rule in Germany) may be counterproductive in the light of the results presented in this paper. And finally, it is the duty of the clubs' management to look for additional sources of revenue, for example by entering new markets. It fits into this picture that we have seen some of the most prominent European football clubs touring Asia or the US. 


\section{References}

Bloching, B., \& Pawlowski, T. (2013). How exciting are the major European football leagues? Roland Berger Strategy Consultants Studien.

Czarnitzki, D., \& Stadtmann, G. (2002). Uncertainty of outcome versus reputation: Empirical evidence for the First German Football Division. Empirical Economics 27, 101-112.

D’Andrea, A., \& Masciandaro, D. (2016). Financial fair play in European football: Economics and political economy - a review essay. BAFFI CAREFIN Centre Research Paper No. 2016-15.

Depken, C. A. (1999). Free agency and the competitiveness of Major League Baseball. Review of Industrial Organization 14, 205-217.

Fort, R., \& Quirk, J. (2004). Owner objectives and competitive balance. Journal of Sports Economics 5, $20-32$

Franck, E. (2014). Financial fair play in European club football - What is it all about? International Journal of Sport Finance 3, 193-217.

Gerhards, J., Mutz, M., \& Wagner, G. G. (2014). Die Berechnung des Siegers: Marktwert, Ungleichheit, Diversität und Routine als Einflussfaktoren auf die Leistung professioneller Fußballteams. Zeitschrift für Soziologie 43, 231-250.

Goossens, K. (2006). Competitive balance in European football: Comparison by adapting measures: National measure of seasonal imbalance and Top 3. Rivista di Diritto ed Economia dello Sport 2, 77 122.

Hamil, S., \& Hassan, D. (2013). Who owns football? Models of football governance and management in international sport: The governance and management of the club game worldwide. Routledge Chapman \& Hall, Abingdon, Oxfordshire.

Hirschman, A. O. (1964). The paternity of an index. American Economic Review 54, 761. 
Humphreys, B. (2002). Alternative measures of competitive balance in sports leagues. Journal of Sports Economics 3, 133-148.

Janssens, P., \& Késenne, S. (1987). Belgian football attendances. Tijdschrift voor Economie en Management 32, 305-315.

Kaplan, V. (2015). UEFA Financial Fair Play regulations and European Union antitrust law complications. Emory International Law Review 29, 799-857.

Madden, P. (2012). Welfare economics of "financial fair play" in a sports league with benefactor owners. Journal of Sports Economic 16, 159-184.

Madden, P. (2014). Does break-even regulation of soccer clubs make sense? University of Manchester, School of Economics Discussion Paper Series 1405.

Michie, J., \& Oughton, C. (2004). Competitive balance in football: Trends and effects. Football Governance Research Centre, Research Paper No. 2.

Pawlowski, T. (2013). Wettbewerbsintensität im Fußball: Eine empirische Untersuchung zur Bedeutung für die Zuschauer. Springer Fachmedien, Wiesbaden.

Peeters, T., \& Szymanski, S. (2014). Financial fair play in European football. Economic Policy 29, 343390.

Petersen, M. A. (2009). Estimating standard errors in finance panel data sets: Comparing approaches. Review of Financial Studies 22, 435-480.

Pope, P., \& Peel, D. (1989). Information, prices and efficiency in a fixed-odds betting market. Economica 56, p. 323-341.

Preuss, H., Haugen, K. K., \& Schubert, M. (2014). UEFA Financial Fair Play: The curse of regulation. European Journal of Sport Studies 2, 33-51. 
Roberts, M.R., \& Whited, T. (2012). Endogeneity in empirical corporate finance. In: George Constantinides, Milton Harris, and Rene Stulz, eds. Handbook of the Economics of Finance Volume 2.

Sass, M. (2012). Long-term competitive balance under UEFA Financial Fair Play Regulations. Working Paper No. 5/2012, Otto-von-Guericke University Magdeburg.

Soriano, F. (2014). Building a result driven organization: Management lessons from the world of football. Speech at the Government Summit, Dubai, February 11, 2014.

Teichmann, K. (2007). Strategie und Erfolg von Fußballunternehmen. Springer-Verlag, Wiesbaden.

Theil, H. (1967). Economics and information theory. North Holland, Amsterdam.

UEFA (2010). UEFA Club Licensing and Financial Fair Play Regulations. Edition 2010.

UEFA (2012). UEFA Club Licensing and Financial Fair Play Regulations. Edition 2012.

UEFA (2013). The European Club Licensing Benchmarking Report Financial Year 2011.

UEFA (2015). UEFA Club Licensing and Financial Fair Play Regulations. Edition 2015.

Vöpel, H. (2013). Is financial fair play really justified? An economic and legal assessment of UEFA's Financial Fair Play rules. Hamburg Institute of International Economics Policy Paper No. 79. 


\section{Appendix A: Overview of all investor payments in the dataset}

\begin{tabular}{|c|c|c|c|c|}
\hline League & Season & Club & Investment & Investors \\
\hline Bundesliga & $2004 / 05$ & FC Bayern München & $2.000 \mathrm{~m} €$ & Adidas \\
\hline Bundesliga & $2004 / 05$ & Bayer 04 Leverkusen & $2.500 \mathrm{~m} €$ & Bayer \\
\hline Bundesliga & $2004 / 05$ & VfL Wolfsburg & $7.000 \mathrm{~m} €$ & Volkswagen \\
\hline Bundesliga & $2005 / 06$ & FC Bayern München & $2.000 \mathrm{~m} €$ & Adidas \\
\hline Bundesliga & $2005 / 06$ & Bayer 04 Leverkusen & $2.500 \mathrm{~m} €$ & Bayer \\
\hline Bundesliga & $2005 / 06$ & VfL Wolfsburg & $7.000 \mathrm{~m} €$ & Volkswagen \\
\hline Bundesliga & $2005 / 06$ & FC Schalke 04 & $7.750 \mathrm{~m} €$ & Clemens Tönnies \\
\hline Bundesliga & $2006 / 07$ & FC Bayern München & $2.000 \mathrm{~m} €$ & Adidas \\
\hline Bundesliga & $2006 / 07$ & Bayer 04 Leverkusen & $2.500 \mathrm{~m} €$ & Bayer \\
\hline Bundesliga & $2006 / 07$ & VfL Wolfsburg & $7.000 \mathrm{~m} €$ & Volkswagen \\
\hline Bundesliga & $2007 / 08$ & FC Bayern München & $2.000 \mathrm{~m} €$ & Adidas \\
\hline Bundesliga & $2007 / 08$ & Bayer 04 Leverkusen & $2.500 \mathrm{~m} €$ & Bayer \\
\hline Bundesliga & $2007 / 08$ & VfL Wolfsburg & $7.000 \mathrm{~m} €$ & Volkswagen \\
\hline Bundesliga & $2008 / 09$ & FC Bayern München & $2.000 \mathrm{~m} €$ & Adidas \\
\hline Bundesliga & 2008/09 & Bayer 04 Leverkusen & $2.500 \mathrm{~m} €$ & Bayer \\
\hline Bundesliga & $2008 / 09$ & VfL Wolfsburg & $62.500 \mathrm{~m} €$ & Volkswagen \\
\hline Bundesliga & 2008/09 & TSG 1899 Hoffenheim & $41.263 \mathrm{~m} €$ & Dietmar Hopp \\
\hline Bundesliga & 2008/09 & 1. FC Köln & $1.000 \mathrm{~m} €$ & Franz-Joseph Wernze \\
\hline Bundesliga & $2009 / 10$ & FC Bayern München & $2.000 \mathrm{~m} €$ & Adidas \\
\hline Bundesliga & $2009 / 10$ & Bayer 04 Leverkusen & $2.500 \mathrm{~m} €$ & Bayer \\
\hline Bundesliga & $2009 / 10$ & VfL Wolfsburg & $67.500 \mathrm{~m} €$ & Volkswagen \\
\hline Bundesliga & $2009 / 10$ & TSG 1899 Hoffenheim & $79.433 \mathrm{~m} €$ & Dietmar Hopp \\
\hline Bundesliga & $2009 / 10$ & 1. FC Köln & $1.000 \mathrm{~m} €$ & Franz-Joseph Wernze \\
\hline Bundesliga & 2010/11 & FC Bayern München & $102.000 \mathrm{~m} €$ & Adidas, Audi \\
\hline Bundesliga & $2010 / 11$ & Bayer 04 Leverkusen & $2.500 \mathrm{~m} €$ & Bayer \\
\hline Bundesliga & 2010/11 & VfL Wolfsburg & $67.500 \mathrm{~m} €$ & Volkswagen \\
\hline Bundesliga & 2010/11 & TSG 1899 Hoffenheim & $118.320 \mathrm{~m} €$ & Dietmar Hopp \\
\hline Bundesliga & 2010/11 & 1. FC Köln & $0.475 \mathrm{~m} €$ & Franz-Joseph Wernze \\
\hline Bundesliga & $2010 / 11$ & Hamburger SV & $12.500 \mathrm{~m} €$ & Klaus-Michael Kühne \\
\hline Bundesliga & 2010/11 & Eintracht Frankfurt & $2.000 \mathrm{~m} €$ & Friends of Eintracht Frankfurt AG (4 banks) \\
\hline Bundesliga & $2011 / 12$ & FC Bayern München & $32.200 \mathrm{~m} €$ & Adidas, Audi \\
\hline Bundesliga & $2011 / 12$ & Bayer 04 Leverkusen & $2.500 \mathrm{~m} €$ & Bayer \\
\hline Bundesliga & 2011/12 & VfL Wolfsburg & $67.500 \mathrm{~m} €$ & Volkswagen \\
\hline Bundesliga & 2011/12 & TSG 1899 Hoffenheim & $-1.716 \mathrm{~m} €$ & Dietmar Hopp \\
\hline Bundesliga & $2011 / 12$ & 1. FC Köln & $-0.051 \mathrm{~m} €$ & Franz-Joseph Wernze \\
\hline Bundesliga & $2012 / 13$ & FC Bayern München & $32.200 \mathrm{~m} €$ & Adidas, Audi \\
\hline Bundesliga & $2012 / 13$ & Bayer 04 Leverkusen & $2.500 \mathrm{~m} €$ & Bayer \\
\hline Bundesliga & $2012 / 13$ & VfL Wolfsburg & $67.500 \mathrm{~m} €$ & Volkswagen \\
\hline Bundesliga & $2012 / 13$ & TSG 1899 Hoffenheim & $12.740 \mathrm{~m} €$ & Dietmar Hopp \\
\hline Bundesliga & $2012 / 13$ & Eintracht Frankfurt & $1.250 \mathrm{~m} €$ & Friends of Eintracht Frankfurt AG (4 banks) \\
\hline Bundesliga & $2012 / 13$ & Hamburger SV & $8.000 \mathrm{~m} €$ & Klaus-Michael Kühne \\
\hline Bundesliga & $2012 / 13$ & Hannover 96 & $12.500 \mathrm{~m} €$ & Investor group around Martin Kind \\
\hline Bundesliga & $2012 / 13$ & FC Augsburg & $1.000 \mathrm{~m} €$ & Klaus Hofmann \\
\hline Bundesliga & $2013 / 14$ & FC Bayern München & $148.200 \mathrm{~m} €$ & Adidas, Audi, Allianz \\
\hline Bundesliga & 2013/14 & Bayer 04 Leverkusen & $25.200 \mathrm{~m} €$ & Bayer \\
\hline Bundesliga & 2013/14 & VfL Wolfsburg & $67.500 \mathrm{~m} €$ & Volkswagen \\
\hline Bundesliga & $2013 / 14$ & Hertha BSC Berlin & $61.200 \mathrm{~m} €$ & KKR \\
\hline Bundesliga & $2013 / 14$ & Eintracht Braunschweig & $-2.700 \mathrm{~m} €$ & Michael Kölmel \\
\hline Bundesliga & $2014 / 15$ & FC Bayern München & $36.000 \mathrm{~m} €$ & Adidas, Audi, Allianz \\
\hline Bundesliga & $2014 / 15$ & Bayer 04 Leverkusen & $75.000 \mathrm{~m} €$ & Bayer \\
\hline Bundesliga & $2014 / 15$ & VfL Wolfsburg & $67.500 \mathrm{~m} €$ & Volkswagen \\
\hline Bundesliga & 2014/15 & Borussia Dortmund & $162.994 \mathrm{~m} €$ & Evonik, Signal Iduna, Puma \\
\hline Bundesliga & $2014 / 15$ & 1. FC Köln & $-1.547 \mathrm{~m} €$ & Franz-Josef Wernze \\
\hline Bundesliga & $2014 / 15$ & Hamburger SV & $17.000 \mathrm{~m} €$ & Klaus-Michael Kühne \\
\hline 2. Bundesliga & 2005/06 & Eintracht Braunschweig & $-0.200 \mathrm{~m} €$ & Michael Kölmel \\
\hline
\end{tabular}




\begin{tabular}{|c|c|c|c|c|}
\hline 2. Bundesliga & $2006 / 07$ & Eintracht Braunschweig & $-0.200 \mathrm{~m} €$ & Michael Kölmel \\
\hline 2. Bundesliga & $2006 / 07$ & FC Augsburg & $25.000 \mathrm{~m} €$ & Investor group around Walther Seinsch \\
\hline 2. Bundesliga & $2007 / 08$ & TSG 1899 Hoffenheim & $63.312 \mathrm{~m} €$ & Dietmar Hopp \\
\hline 2. Bundesliga & $2011 / 12$ & TSV 1860 München & $23.860 \mathrm{~m} €$ & Hasan Ismaik \\
\hline 2. Bundesliga & $2011 / 12$ & 1. FC Union Berlin & $-0.400 \mathrm{~m} €$ & Michael Kölmel \\
\hline 2. Bundesliga & $2011 / 12$ & Eintracht Braunschweig & $-1.000 \mathrm{~m} €$ & Michael Kölmel \\
\hline 2. Bundesliga & $2011 / 12$ & Dynamo Dresden & $-0.380 \mathrm{~m} €$ & Michael Kölmel \\
\hline 2. Bundesliga & $2012 / 13$ & Eintracht Braunschweig & $-1.000 \mathrm{~m} €$ & Michael Kölmel \\
\hline 2. Bundesliga & $2012 / 13$ & 1. FC Köln & $-1.565 \mathrm{~m} €$ & Franz-Josef Wernze \\
\hline 2. Bundesliga & $2012 / 13$ & TSV 1860 München & $3.500 \mathrm{~m} €$ & Hasan Ismaik \\
\hline 2. Bundesliga & $2012 / 13$ & 1. FC Union Berlin & $-0.700 \mathrm{~m} €$ & Michael Kölmel \\
\hline 2. Bundesliga & $2012 / 13$ & MSV Duisburg & $0.600 \mathrm{~m} €$ & Walter Hellmich \\
\hline 2. Bundesliga & $2012 / 13$ & FC Ingolstadt 04 & $6.500 \mathrm{~m} €$ & Volkswagen group (Quattro GmbH) \\
\hline 2. Bundesliga & $2012 / 13$ & Dynamo Dresden & $-0.450 \mathrm{~m} €$ & Michael Kölmel \\
\hline 2. Bundesliga & $2013 / 14$ & 1. FC Köln & $-0.620 m €$ & Franz-Josef Wernze \\
\hline 2. Bundesliga & $2013 / 14$ & TSV 1860 München & $1.200 \mathrm{~m} €$ & Hasan Ismaik \\
\hline 2. Bundesliga & $2013 / 14$ & 1. FC Union Berlin & $-1.000 \mathrm{~m} €$ & Michael Kölmel \\
\hline 2. Bundesliga & $2013 / 14$ & Fortuna Düsseldorf & $-3.900 \mathrm{~m} €$ & Michael Kölmel \\
\hline 2. Bundesliga & $2013 / 14$ & FC Ingolstadt 04 & $6.500 \mathrm{~m} €$ & Volkswagen group (Quattro GmbH) \\
\hline 2. Bundesliga & $2013 / 14$ & Dynamo Dresden & $-0.439 m €$ & Michael Kölmel \\
\hline 2. Bundesliga & $2014 / 15$ & FC Ingolstadt 04 & $3.000 \mathrm{~m} €$ & Volkswagen group (Quattro GmbH) \\
\hline 2. Bundesliga & $2014 / 15$ & RB Leipzig & $10.000 \mathrm{~m} €$ & Red Bull \\
\hline 2. Bundesliga & $2014 / 15$ & Eintracht Braunschweig & $-1.400 \mathrm{~m} €$ & Michael Kölmel \\
\hline 2. Bundesliga & $2014 / 15$ & Fortuna Düsseldorf & $-0.400 \mathrm{~m} €$ & Michael Kölmel \\
\hline Premier League & $2004 / 05$ & Chelsea & $95.590 \mathrm{~m} €$ & Roman Arkadjewitsch Abramowitsch \\
\hline Premier League & $2004 / 05$ & Bolton Wanderers & $18.009 \mathrm{~m} €$ & Eddie Davies \\
\hline Premier League & $2004 / 05$ & Aston Villa & $-0.375 \mathrm{~m} €$ & Doug Ellis \\
\hline Premier League & $2004 / 05$ & Newcastle United & $-5.545 m €$ & Hall Family, Shepherd Family \\
\hline Premier League & $2005 / 06$ & Chelsea & $168.500 \mathrm{~m} €$ & Roman Arkadjewitsch Abramowitsch \\
\hline Premier League & $2005 / 06$ & Newcastle United & $-5.225 \mathrm{~m} €$ & Hall Family, Shepherd Family \\
\hline Premier League & $2005 / 06$ & Bolton Wanderers & $17.409 \mathrm{~m} €$ & Eddie Davies \\
\hline Premier League & $2005 / 06$ & Aston Villa & $-0.421 \mathrm{~m} €$ & Doug Ellis \\
\hline Premier League & $2006 / 07$ & Chelsea & $142.150 \mathrm{~m} €$ & Roman Arkadjewitsch Abramowitsch \\
\hline Premier League & $2006 / 07$ & Liverpool & $64.960 \mathrm{~m} €$ & George Gillett and Tom Hicks \\
\hline Premier League & $2006 / 07$ & Bolton Wanderers & $17.409 \mathrm{~m} €$ & Eddie Davies \\
\hline Premier League & $2006 / 07$ & West Ham United & $-1.500 \mathrm{~m} €$ & Eggert Magnusson and Björgolfur Guomundsson \\
\hline Premier League & $2007 / 08$ & Newcastle United & $203.000 \mathrm{~m} €$ & Mike Ashley \\
\hline Premier League & $2007 / 08$ & Bolton Wanderers & $16.208 \mathrm{~m} €$ & Eddie Davies \\
\hline Premier League & $2008 / 09$ & Aston Villa & $131.250 \mathrm{~m} €$ & Randolph Lerner \\
\hline Premier League & $2008 / 09$ & Manchester City & $299.650 \mathrm{~m} €$ & Sheikh Mansour bin Zayed Al Nahyan \\
\hline Premier League & $2008 / 09$ & Bolton Wanderers & $13.807 \mathrm{~m} €$ & Eddie Davies \\
\hline Premier League & $2008 / 09$ & Sunderland AFC & $77.625 \mathrm{~m} €$ & Drumaville consortium \\
\hline Premier League & $2009 / 10$ & Tottenham Hotspur & $48.000 \mathrm{~m} €$ & Joe Lewis \\
\hline Premier League & $2009 / 10$ & Manchester City & $140.350 \mathrm{~m} €$ & Sheikh Mansour bin Zayed Al Nahyan \\
\hline Premier League & $2009 / 10$ & Aston Villa & $2.415 \mathrm{~m} €$ & Randolph Lerner \\
\hline Premier League & $2009 / 10$ & Birmingham City & $17.250 \mathrm{~m} €$ & Carson Yeung \\
\hline Premier League & $2009 / 10$ & Sunderland AFC & $54.050 \mathrm{~m} €$ & Ellis Short \\
\hline Premier League & $2009 / 10$ & Bolton Wanderers & $14.907 \mathrm{~m} €$ & Eddie Davies \\
\hline Premier League & $2009 / 10$ & West Ham United & $39.100 \mathrm{~m} €$ & David Sullivan and David Gold \\
\hline Premier League & $2010 / 11$ & Chelsea & $51.350 \mathrm{~m} €$ & Roman Arkadjewitsch Abramowitsch \\
\hline Premier League & $2010 / 11$ & Manchester City & $347.050 \mathrm{~m} €$ & Sheikh Mansour bin Zayed Al Nahyan \\
\hline Premier League & $2010 / 11$ & Sunderland AFC & $3.450 \mathrm{~m} €$ & Ellis Short \\
\hline Premier League & $2010 / 11$ & Bolton Wanderers & $12.708 \mathrm{~m} €$ & Eddie Davies \\
\hline Premier League & $2010 / 11$ & Blackburn Rovers & $24.000 \mathrm{~m} €$ & Rao Family (V H Group - Venky’s London Ltd.) \\
\hline Premier League & $2010 / 11$ & Blackpool & $-13.200 \mathrm{~m} €$ & Owen John Oysten \\
\hline Premier League & $2010 / 11$ & West Ham United & $2.300 \mathrm{~m} €$ & David Sullivan and David Gold \\
\hline Premier League & $2011 / 12$ & Manchester City & $112.950 \mathrm{~m} €$ & Sheikh Mansour bin Zayed Al Nahyan \\
\hline Premier League & $2012 / 13$ & Manchester City & $46.600 \mathrm{~m} €$ & Sheikh Mansour bin Zayed Al Nahyan \\
\hline Premier League & $2012 / 13$ & Swansea City & $-0.999 \mathrm{~m} €$ & Morgan Family and Brian Katzen \\
\hline
\end{tabular}




\begin{tabular}{|c|c|c|c|c|}
\hline Premier League & $2012 / 13$ & Stoke City & $4.083 \mathrm{~m} €$ & Peter Coates (bet365) \\
\hline Premier League & 2013/14 & Manchester City & $230.600 \mathrm{~m} €$ & Sheikh Mansour bin Zayed Al Nahyan \\
\hline Premier League & 2013/14 & Stoke City & $4.083 \mathrm{~m} €$ & Peter Coates (bet365) \\
\hline Premier League & $2014 / 15$ & Manchester City & $151.975 \mathrm{~m} €$ & Sheikh Mansour bin Zayed Al Nahyan \\
\hline Premier League & $2014 / 15$ & Liverpool & $190.000 \mathrm{~m} €$ & John W. Henry (Fenway Sports Group) \\
\hline Premier League & $2014 / 15$ & Stoke City & $4.083 \mathrm{~m} €$ & Peter Coates (bet365) \\
\hline Premier League & $2014 / 15$ & Leicester City & $30.080 \mathrm{~m} €$ & Srivaddhanaprabha Family \\
\hline Championship & 2006/07 & Stoke City & $4.785 \mathrm{~m} €$ & Peter Coates (bet365) \\
\hline Championship & 2007/08 & Stoke City & $8.100 \mathrm{~m} €$ & Peter Coates (bet365) \\
\hline Championship & $2007 / 08$ & Wolverhampton Wanderers & $30.000 \mathrm{~m} €$ & Steve Morgan \\
\hline Championship & $2007 / 08$ & Queens Park Rangers & $18.200 \mathrm{~m} €$ & Flavio Briatore \\
\hline Championship & 2007/08 & Norwich City & $2.900 \mathrm{~m} €$ & Delia Smith and Michael Wynn-Jones \\
\hline Championship & $2007 / 08$ & Coventry City & $12.767 \mathrm{~m} €$ & Ray Ranson \\
\hline Championship & $2008 / 09$ & Norwich City & $2.500 \mathrm{~m} €$ & Delia Smith and Michael Wynn-Jones \\
\hline Championship & $2009 / 10$ & Blackpool & $-0.693 m €$ & Owen John Oysten \\
\hline Championship & $2010 / 11$ & Norwich City & $2.400 \mathrm{~m} €$ & Michael Foulger \\
\hline Championship & $2010 / 11$ & Cardiff City & $45.339 \mathrm{~m} €$ & Investor group around Vincent Tan \\
\hline Championship & 2010/11 & Leicester City & $8.690 \mathrm{~m} €$ & Srivaddhanaprabha Family \\
\hline Championship & $2010 / 11$ & Hull City & $34.252 \mathrm{~m} €$ & Allam Family \\
\hline Championship & $2011 / 12$ & Cardiff City & $1.001 \mathrm{~m} €$ & Investor group around Vincent Tan \\
\hline Championship & $2011 / 12$ & Hull City & $1.610 \mathrm{~m} €$ & Allam Family \\
\hline Championship & $2011 / 12$ & Leicester City & $21.150 \mathrm{~m} €$ & Srivaddhanaprabha Family \\
\hline Championship & $2012 / 13$ & Cardiff City & $14.425 \mathrm{~m} €$ & Investor group around Vincent Tan \\
\hline Championship & $2012 / 13$ & Hull City & $8.440 \mathrm{~m} €$ & Allam Family \\
\hline Championship & $2012 / 13$ & Leicester City & $9.070 \mathrm{~m} €$ & Srivaddhanaprabha Family \\
\hline Championship & 2013/14 & Leicester City & $3.700 \mathrm{~m} €$ & Srivaddhanaprabha Family \\
\hline Ligue 1 & $2011 / 12$ & Paris Saint-Germain & $128.000 \mathrm{~m} €$ & Qatari ruling family \\
\hline Ligue 1 & $2012 / 13$ & Paris Saint-Germain & $145.000 \mathrm{~m} €$ & Qatari ruling family \\
\hline Ligue 1 & $2013 / 14$ & Paris Saint-Germain & $175.000 \mathrm{~m} €$ & Qatari ruling family \\
\hline Ligue 1 & 2013/14 & AS Monaco & $113.850 \mathrm{~m} €$ & Dmitri Jewgenjewitsch Rybolowlew \\
\hline Ligue 1 & $2014 / 15$ & Paris Saint-Germain & $195.000 \mathrm{~m} €$ & Qatari ruling family \\
\hline Ligue 2 & $2012 / 13$ & AS Monaco & $21.150 \mathrm{~m} €$ & Dmitri Jewgenjewitsch Rybolowlew \\
\hline Serie A & $2004 / 05$ & US Palermo & $12.580 \mathrm{~m} €$ & Maurizio Zamparini \\
\hline Serie A & $2005 / 06$ & Inter & $9.340 \mathrm{~m} €$ & Massimo Moratti \\
\hline Serie A & $2005 / 06$ & US Palermo & $6.600 \mathrm{~m} €$ & Maurizio Zamparini \\
\hline Serie A & $2006 / 07$ & Inter & $10.300 \mathrm{~m} €$ & Massimo Moratti \\
\hline Serie A & $2006 / 07$ & AC Milan & $75.000 \mathrm{~m} €$ & Berlusconi Family (Fininvest) \\
\hline Serie A & $2007 / 08$ & Juventus & $81.875 \mathrm{~m} €$ & Agnelli Family (Exor) \\
\hline Serie A & $2007 / 08$ & AC Milan & $93.000 \mathrm{~m} €$ & Berlusconi Family (Fininvest) \\
\hline Serie A & 2007/08 & US Palermo & $5.070 \mathrm{~m} €$ & Maurizio Zamparini \\
\hline Serie A & 2008/09 & Inter & $95.000 \mathrm{~m} €$ & Massimo Moratti \\
\hline Serie A & $2008 / 09$ & Juventus & $11.000 \mathrm{~m} €$ & Agnelli Family (Exor) \\
\hline Serie A & 2008/09 & AC Milan & $18.000 \mathrm{~m} €$ & Berlusconi Familiy (Fininvest) \\
\hline Serie A & 2008/09 & US Palermo & $9.360 \mathrm{~m} €$ & Maurizio Zamparini \\
\hline Serie A & $2009 / 10$ & Inter & $120.000 \mathrm{~m} €$ & Massimo Moratti \\
\hline Serie A & $2009 / 10$ & AC Milan & $44.000 \mathrm{~m} €$ & Berlusconi Familiy (Fininvest) \\
\hline Serie A & $2009 / 10$ & Juventus & $11.000 \mathrm{~m} €$ & Agnelli Family (Exor) \\
\hline Serie A & $2010 / 11$ & AC Milan & $87.000 \mathrm{~m} €$ & Berlusconi Familiy (Fininvest) \\
\hline Serie A & $2011 / 12$ & Juventus & $80.980 \mathrm{~m} €$ & Agnelli Family (Exor) \\
\hline Serie A & 2011/12 & AC Milan & $29.000 \mathrm{~m} €$ & Berlusconi Familiy (Fininvest) \\
\hline Serie A & $2012 / 13$ & Juventus & $11.667 \mathrm{~m} €$ & Agnelli Family (Exor) \\
\hline Serie A & $2012 / 13$ & Atalanta & $2.250 \mathrm{~m} €$ & Antonio Percassi \\
\hline Serie A & 2013/14 & Juventus & $11.667 \mathrm{~m} €$ & Agnelli Family (Exor) \\
\hline Serie A & 2013/14 & Inter & $200.000 \mathrm{~m} €$ & Erick Thohir \\
\hline Primera División & $2008 / 09$ & Valencia & $50.000 \mathrm{~m} €$ & Company group Fomento Urbano de Castellon \\
\hline Primera División & 2010/11 & Málaga & $75.050 \mathrm{~m} €$ & Sheikh Abdullah Al Thani \\
\hline Primera División & $2011 / 12$ & Málaga & $59.250 \mathrm{~m} €$ & Sheikh Abdullah Al Thani \\
\hline Primera División & $2014 / 15$ & Atlético Madrid & $30.000 \mathrm{~m} €$ & Wang Jianlin \\
\hline Primera División & $2014 / 15$ & Valencia & $60.000 \mathrm{~m} €$ & Peter Lim \\
\hline
\end{tabular}




\section{Appendix B: Robustness tests}

\begin{tabular}{|c|c|c|c|c|c|c|c|c|c|c|}
\hline Dep. variable & $\begin{array}{c}\text { (Ia) } \\
\text { Theil } \\
\text { index }\end{array}$ & $\begin{array}{c}(\mathrm{Ib}) \\
\mathrm{C} 5 \mathrm{ICB}\end{array}$ & $\begin{array}{l}\text { (IIa) } \\
\text { Theil } \\
\text { index }\end{array}$ & $\begin{array}{c}(\mathrm{IIb}) \\
\text { C5ICB }\end{array}$ & $\begin{array}{c}\text { (IIc) } \\
\text { Theil } \\
\text { index }\end{array}$ & $\begin{array}{c}\text { (IId) } \\
\text { C5ICB }\end{array}$ & $\begin{array}{l}\text { (IIIa) } \\
\text { Theil } \\
\text { index }\end{array}$ & $\begin{array}{c}\text { (IIIb) } \\
\text { C5ICB }\end{array}$ & $\begin{array}{l}\text { (IVa) } \\
\text { Theil } \\
\text { index }\end{array}$ & $\begin{array}{c}\text { (IVb) } \\
\text { C5ICB }\end{array}$ \\
\hline Top4 league & & & $\begin{array}{c}0.644 \\
(0.744)\end{array}$ & $\begin{array}{l}-1.180 \\
(3.245)\end{array}$ & $\begin{array}{c}0.661 \\
(0.675)\end{array}$ & $\begin{array}{l}-1.127 \\
(2.931)\end{array}$ & $\begin{array}{c}-0.324 \\
(0.263)\end{array}$ & $\begin{array}{l}-1.858 \\
(1.378)\end{array}$ & $\begin{array}{l}-0.163 \\
(0.571)\end{array}$ & $\begin{array}{c}-1.342 \\
(2.750)\end{array}$ \\
\hline Market value heterogeneity & & & $\begin{array}{c}-0.844 \\
(0.488)\end{array}$ & $\begin{array}{l}-0.743 \\
(1.857)\end{array}$ & $\begin{array}{l}-0.808 \\
(0.561)\end{array}$ & $\begin{array}{c}-0.924 \\
(1.932)\end{array}$ & $\begin{array}{l}-1.862 \\
(1.083)\end{array}$ & $\begin{array}{l}-0.229 \\
(3.721)\end{array}$ & $\begin{array}{c}-1.968 * \\
(1.043)\end{array}$ & $\begin{array}{l}-1.236 \\
(5.205)\end{array}$ \\
\hline Positive cash inflow & & & $\begin{array}{c}-0.0554 \\
(2.155)\end{array}$ & $\begin{array}{c}35.03 * * \\
(10.92)\end{array}$ & $\begin{array}{l}-0.595 \\
(2.001)\end{array}$ & $\begin{array}{c}36.56 * * \\
(13.23)\end{array}$ & $\begin{array}{c}3.912 \\
(3.909) \\
\end{array}$ & $\begin{array}{c}16.85 \\
(9.351) \\
\end{array}$ & $\begin{array}{c}2.970 \\
(3.652) \\
\end{array}$ & $\begin{array}{c}28.01 * * \\
(11.88)\end{array}$ \\
\hline First League * FFP & $\begin{array}{c}-2.789 * * \\
(1.096)\end{array}$ & $\begin{array}{c}-7.495 * \\
(3.482)\end{array}$ & $\begin{array}{c}-1.345 * \\
(0.727)\end{array}$ & $\begin{array}{c}-9.360 * * \\
(3.774)\end{array}$ & $\begin{array}{c}-1.408 * \\
(0.690)\end{array}$ & $\begin{array}{l}-9.036 * \\
(4.074)\end{array}$ & & & & \\
\hline Foreign test games & & & $\begin{array}{c}1.393 \\
(3.126)\end{array}$ & $\begin{array}{l}-5.511 \\
(17.82)\end{array}$ & & & & & & \\
\hline $\mathrm{SD}$ (Foreign test games) & & & & & $\begin{array}{c}0.423 \\
(0.378) \\
\end{array}$ & $\begin{array}{l}-0.519 \\
(2.466) \\
\end{array}$ & & & & \\
\hline First League * Placebo & & & & & & & $\begin{array}{c}-0.727 \\
(0.890)\end{array}$ & $\begin{array}{c}-0.298 \\
(4.415)\end{array}$ & $\begin{array}{c}-0.296 \\
(1.339)\end{array}$ & $\begin{array}{c}-3.541 \\
(6.697)\end{array}$ \\
\hline Season fixed effects & Yes & Yes & Yes & Yes & Yes & Yes & Yes & Yes & Yes & Yes \\
\hline League fixed effects & Yes & Yes & Yes & Yes & Yes & Yes & Yes & Yes & Yes & Yes \\
\hline Observations & 110 & 110 & 50 & 50 & 50 & 50 & 60 & 60 & 50 & 50 \\
\hline $\mathrm{R}^{2}$ & 0.867 & 0.654 & 0.969 & 0.737 & 0.969 & 0.736 & 0.911 & 0.690 & 0.920 & 0.734 \\
\hline
\end{tabular}

The dependent variables are different measures of competition in European football leagues (Section 4). One observation corresponds to one league in a given year. In Models II, the table is restricted to observations after 2009. In Models III (IV), the sample is restricted to observations before 2011 (2010). The financial fair play (FFP) dummy is an indicator variable, which is set to one after 2013 and zero otherwise. First League is a dummy set to one for the highest football leagues and zero otherwise. Top4 league is a dummy variable which is set to one if a league's underlying national team was among the four best teams at the preceding world or European championships, and zero otherwise. Market value heterogeneity is the standard deviation of the clubs' average player market values in a given league and season (in $\mathrm{m} €$ ). Positive cash inflow denotes the fraction of clubs with at least one investor with an overall positive cash contribution to the club. Foreign test games reflects the share of football clubs in a given league and season that performed test games against teams from other countries. $\mathrm{SD}$ (Foreign test games) is the standard deviation of the number of test games against foreign teams before the start of the season, calculated per league and season. Models III perform placebo tests. The Placebo dummy is set to one after 2009 (2008) in Model III (IV), and zero otherwise. Huber/White robust standard errors clustered by football league are presented in parentheses. ${ }^{* *},{ }^{* *}$, and * indicate significance at the $1 \%-, 5 \%-$, and $10 \%$-levels, respectively. 


\section{Appendix C: Further robustness tests}

\begin{tabular}{|c|c|c|c|c|c|c|c|c|}
\hline Dep. variable & $\begin{array}{c}\text { (Ia) } \\
\text { Theil index }\end{array}$ & $\begin{array}{c}\text { (Ib) } \\
\text { C5ICB }\end{array}$ & $\begin{array}{c}\text { (IIa) } \\
\text { Theil index }\end{array}$ & $\begin{array}{c}\text { (IIb) } \\
\text { C5ICB }\end{array}$ & $\begin{array}{c}\text { (IIIa) } \\
\text { Theil index }\end{array}$ & $\begin{array}{c}\text { (IIIb) } \\
\text { C5ICB }\end{array}$ & $\begin{array}{c}\text { (IVa) } \\
\text { Theil index }\end{array}$ & $\begin{array}{c}\text { (IVb) } \\
\text { C5ICB }\end{array}$ \\
\hline Top4 league & $\begin{array}{c}0.956 \\
(1.039)\end{array}$ & $\begin{array}{c}1.174 \\
(0.791)\end{array}$ & $\begin{array}{c}0.966 \\
(0.923)\end{array}$ & $\begin{array}{c}1.007 \\
(0.936)\end{array}$ & $\begin{array}{c}1.049 \\
(1.068)\end{array}$ & $\begin{array}{c}1.055 \\
(0.918)\end{array}$ & $\begin{array}{c}0.993 \\
(0.895)\end{array}$ & $\begin{array}{c}0.982 \\
(0.914)\end{array}$ \\
\hline Market value heterogeneity & $\begin{array}{l}-1.237 \\
(1.334)\end{array}$ & $\begin{array}{c}-0.277 \\
(1.179)\end{array}$ & $\begin{array}{l}-1.196^{*} \\
(0.643)\end{array}$ & $\begin{array}{l}-1.061 \\
(0.617)\end{array}$ & $\begin{array}{l}-1.152 \\
(1.193)\end{array}$ & $\begin{array}{l}-0.272 \\
(1.171)\end{array}$ & $\begin{array}{l}-1.193 * \\
(0.625)\end{array}$ & $\begin{array}{l}-0.996 \\
(0.565)\end{array}$ \\
\hline Positive cash inflow & $\begin{array}{l}12.31 * \\
(5.546)\end{array}$ & & $\begin{array}{l}-0.880 \\
(2.488)\end{array}$ & & $\begin{array}{l}13.65 * * \\
(5.546)\end{array}$ & & $\begin{array}{l}-0.561 \\
(2.592)\end{array}$ & \\
\hline Cash flow heterogeneity & & $\begin{array}{l}0.0484 * \\
(0.0221)\end{array}$ & & $\begin{array}{c}-0.000444 \\
(0.0105)\end{array}$ & & $\begin{array}{l}0.0511 * \\
(0.0231)\end{array}$ & & $\begin{array}{l}0.00314 \\
(0.0134)\end{array}$ \\
\hline Positive cash inflow * FFP & $\begin{array}{c}-1.680 \\
(2.216)\end{array}$ & & $\begin{array}{c}-0.826 \\
(1.435)\end{array}$ & & & & & \\
\hline Cash flow heterogeneity * FFP & & $\begin{array}{r}-0.0722 * \\
(0.0388)\end{array}$ & & $\begin{array}{c}-0.0193 \\
(0.0187)\end{array}$ & & & & \\
\hline Positive cash inflow * FFP (2012) & & & & & $\begin{array}{l}-3.386 \\
(2.131)\end{array}$ & & $\begin{array}{c}-1.203 \\
(1.494)\end{array}$ & \\
\hline Cash flow heterogeneity * FFP (2012) & & & & & & $\begin{array}{c}-0.0780 * \\
(0.0412)\end{array}$ & & $\begin{array}{c}-0.0258 \\
(0.0219)\end{array}$ \\
\hline Season fixed effects & Yes & Yes & Yes & Yes & Yes & Yes & Yes & Yes \\
\hline League fixed effects & Yes & Yes & Yes & Yes & Yes & Yes & Yes & Yes \\
\hline Observations & 50 & 50 & 50 & 50 & 50 & 50 & 50 & 50 \\
\hline $\mathrm{R}^{2}$ & 0.742 & 0.743 & 0.961 & 0.963 & 0.750 & 0.746 & 0.961 & 0.964 \\
\hline
\end{tabular}

The dependent variables are different measures of competition in European football leagues (Section 4). One observation corresponds to one league in a given year. The table is restricted to observations after 2009. The financial fair play (FFP) dummy is an indicator variable, which is set to one after 2013 and zero

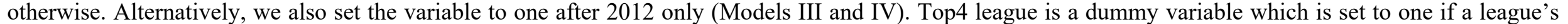

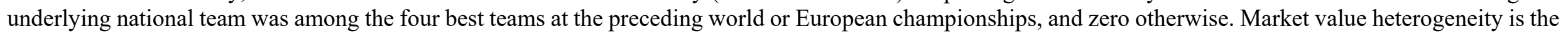
standard deviation of the clubs' average player market values in a given league and season (in m€). Positive cash inflow denotes the fraction of clubs with at least

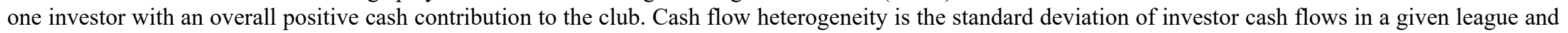

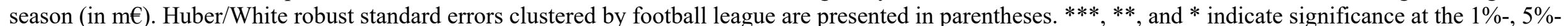
, and $10 \%$-levels, respectively. 